\title{
Dinitrogen fixation and dissolved organic nitrogen fueled primary production and particulate export during the VAHINE mesocosm experiment (New Caledonia lagoon)
}

\author{
H. Berthelot ${ }^{1}$, T. Moutin ${ }^{1}$, S. L'Helguen ${ }^{2}$, K. Leblanc ${ }^{1}$, S. Hélias ${ }^{1}$, O. Grosso ${ }^{1}$, N. Leblond ${ }^{3}$, B. Charrière ${ }^{1, a}$, and \\ S. Bonnet ${ }^{1,4}$ \\ ${ }^{1}$ Aix Marseille Université, CNRS/INSU, Université de Toulon, IRD, Mediterranean Institute of Oceanography (MIO) \\ UM110, 13288, Marseille, France \\ ${ }^{2}$ Université de Brest, CNRS/IRD, UMR6539, Laboratoire des Sciences de l'Environnement Marin, OSU-IUEM, 29280 \\ Plouzané, France \\ ${ }^{3}$ Observatoire Océanologique de Villefranche, Laboratoire d'Océanographie de Villefranche, UMR 7093, \\ Villefranche-sur-mer, France \\ ${ }^{4}$ Mediterranean Institute of Oceanography (MIO) - IRD/CNRS/Aix-Marseille University IRD Noumea, 101 Promenade R. \\ Laroque, BPA5, 98848, Noumea CEDEX, New Caledonia \\ ${ }^{a}$ now at: Centre de Formation et de Recherche sur les Environnements Méditerranéens CNRS UMR5110, Université de \\ Perpignan Via Domitia, 66860 Perpignan, France
}

Correspondence to: H. Berthelot (hugo.berthelot@mio.osupytheas.fr)

Received: 11 February 2015 - Published in Biogeosciences Discuss.: 10 March 2015

Revised: 10 June 2015 - Accepted: 15 June 2015 - Published: 07 July 2015

\begin{abstract}
In the oligotrophic ocean characterized by nitrate $\left(\mathrm{NO}_{3}^{-}\right)$depletion in surface waters, dinitrogen $\left(\mathrm{N}_{2}\right)$ fixation and dissolved organic nitrogen (DON) can represent significant nitrogen $(\mathrm{N})$ sources for the ecosystem. In this study, we deployed large in situ mesocosms in New Caledonia in order to investigate (1) the contribution of $\mathrm{N}_{2}$ fixation and DON use to primary production (PP) and particle export and (2) the fate of the freshly produced particulate organic $\mathrm{N}$ (PON), i.e., whether it is preferentially accumulated and recycled in the water column or exported out of the system. The mesocosms were fertilized with phosphate $\left(\mathrm{PO}_{4}^{3-}\right)$ in order to prevent phosphorus $(\mathrm{P})$ limitation and promote $\mathrm{N}_{2}$ fixation. The diazotrophic community was dominated by diatom-diazotroph associations (DDAs) during the first part of the experiment for 10 days (P1) followed by the unicellular $\mathrm{N}_{2}$-fixing cyanobacteria UCYN-C for the last 9 days (P2) of the experiment. $\mathrm{N}_{2}$ fixation rates averaged $9.8 \pm 4.0$ and $27.7 \pm 8.6 \mathrm{nmol} \mathrm{L}^{-1} \mathrm{~d}^{-1}$ during $\mathrm{P} 1$ and $\mathrm{P} 2$, respectively. $\mathrm{NO}_{3}^{-}$concentrations $\left(<0.04 \mu \mathrm{mol} \mathrm{L}^{-1}\right)$ in the mesocosms were a negligible source of $\mathrm{N}$, indicating that $\mathrm{N}_{2}$ fixation was the main driver of new production throughout the ex-
\end{abstract}

periment. The contribution of $\mathrm{N}_{2}$ fixation to PP was not significantly different $(p>0.05)$ during $\mathrm{P} 1(9.0 \pm 3.3 \%)$ and $\mathrm{P} 2(12.6 \pm 6.1 \%)$. However, the $e$ ratio that quantifies the efficiency of a system to export particulate organic carbon $\left(\mathrm{POC}_{\text {export }}\right)$ compared to $\mathrm{PP}\left(e\right.$ ratio $\left.=\mathrm{POC}_{\text {export }} / \mathrm{PP}\right)$ was significantly higher $(p<0.05)$ during $\mathrm{P} 2(39.7 \pm 24.9 \%)$ than during $\mathrm{P} 1(23.9 \pm 20.2 \%)$, indicating that the production sustained by UCYN-C was more efficient at promoting $\mathrm{C}$ export than the production sustained by DDAs. During $\mathrm{P} 1$, PON was stable and the total amount of $\mathrm{N}$ provided by $\mathrm{N}_{2}$ fixation $\left(0.10 \pm 0.02 \mu \mathrm{mol} \mathrm{L}{ }^{-1}\right)$ was not significantly different $(p>0.05)$ from the total amount of PON exported $\left(0.10 \pm 0.04 \mu \mathrm{mol} \mathrm{L}^{-1}\right)$, suggesting a rapid and probably direct export of the recently fixed $\mathrm{N}_{2}$ by the DDAs. During $\mathrm{P} 2$, both PON concentrations and PON export increased in the mesocosms by a factor 1.5-2. Unlike in P1, this PON production was not totally explained by the new $\mathrm{N}$ provided by $\mathrm{N}_{2}$ fixation. The use of DON, whose concentrations decreased significantly $(p<0.05)$ from $5.3 \pm 0.5 \mu \mathrm{mol} \mathrm{L}^{-1}$ to $4.4 \pm 0.5 \mu \mathrm{mol} \mathrm{L}{ }^{-1}$, appeared to be the missing $\mathrm{N}$ source. The DON consumption $\left(\sim 0.9 \mu \mathrm{mol} \mathrm{L}^{-1}\right)$ during $\mathrm{P} 2$ is higher 
than the total amount of new $\mathrm{N}$ brought by $\mathrm{N}_{2}$ fixation $\left(\sim 0.25 \mu \mathrm{mol} \mathrm{L}{ }^{-1}\right)$ during the same period. These results suggest that while DDAs mainly rely on $\mathrm{N}_{2}$ fixation for their $\mathrm{N}$ requirements, both $\mathrm{N}_{2}$ fixation and DON can be significant $\mathrm{N}$ sources for primary production and particulate export following UCYN-C blooms in the New Caledonia lagoon and by extension in the $\mathrm{N}$-limited oceans where similar events are likely to occur.

\section{Introduction}

Nitrogen (N) availability constitutes one of the most limiting factors for marine primary production (PP) (Moore et al., 2013). About $80 \%$ of the global ocean surface is depleted in dissolved inorganic $\mathrm{N}$ (nitrate $\left(\mathrm{NO}_{3}^{-}\right)$and ammonium $\left(\mathrm{NH}_{4}^{+}\right)$ $<1 \mu \mathrm{mol} \mathrm{L}^{-1}$ ), and characterized by low PP, low biomass and low particulate matter export fluxes (Longhurst, 2007). In these low nitrate, low chlorophyll (LNLC) ecosystems, the strong stratification of the photic surface layer prevents the mixing with $\mathrm{NO}_{3}^{-}$-replete deep waters and requires phytoplanktonic communities to rely on alternative $\mathrm{N}$ sources for growth. These sources comprise the virtually inexhaustible dissolved dinitrogen $\left(\mathrm{N}_{2}\right)$ pool $\left(\sim 400 \mu \mathrm{mol} \mathrm{L}^{-1}\right)$, and the large $\left(\sim 5 \mu \mathrm{mol} \mathrm{L}^{-1}\right)$ but mainly refractory dissolved organic $\mathrm{N}$ (DON) pool.

The first pool $\left(\mathrm{N}_{2}\right)$ is only accessible to diazotrophic organisms able to reduce the $\mathrm{N}_{2}$ gas molecule into bioavailable $\mathrm{NH}_{4}^{+}$. This process called $\mathrm{N}_{2}$ fixation (or diazotrophy) is responsible for the main external source of $\mathrm{N}$ for the upper ocean (Gruber and Galloway, 2008; Mahaffey, 2005) and fuels PP in LNLC ecosystems (e.g., Dugdale and Goering, 1967; Karl et al., 1997). However, the fate of recently fixed $\mathrm{N}_{2}$ in the planktonic food web and its potential impact on carbon export are poorly understood. Moreover, this fate may differ according to the diazotrophic species involved in $\mathrm{N}_{2}$ fixation. The widely distributed filamentous cyanobacterium Trichodesmium spp., one of the main contributors to global $\mathrm{N}_{2}$ fixation (Capone et al., 1997), is rarely found in sediment traps (Chen et al., 2003; Walsby, 1992), indicating that Trichodesmium spp. has a low direct export efficiency. However, a recent study performed in the southwest Pacific indicates that $\mathrm{N}$ fixed by Trichodesmium spp. is preferentially and rapidly (within few days) transferred to diatoms and bacteria (Bonnet et al., 2015b), potentially resulting in indirect carbon export. Conversely, diatom-diazotroph associations (DDAs) drive an efficient biological carbon pump in the Amazon River plume (Subramaniam et al., 2008) and in the North Pacific Gyre (Dore et al., 2008; Karl et al., 2012), indicating efficient export of the $\mathrm{N}$ fixed by these organisms. Finally, unicellular $\mathrm{N}_{2}$-fixing cyanobacteria (UCYN) are presumably the most abundant in the global ocean and are also major contributors to global $\mathrm{N}_{2}$ fixation (e. g. Moisander et al., 2010; Montoya et al., 2004). However, little is known regarding the fate of the $\mathrm{N}$ fixed by UCYN, whether it is directly or indirectly exported out of the euphotic zone or recycled in surface waters (Thompson and Zehr, 2013).

The second $\mathrm{N}$ pool (DON) may constitute a significant $\mathrm{N}$ source for planktonic communities but remains poorly constrained (Bronk, 2002). The DON pool is a "black box" composed of various chemical products more or less refractory with their own specific turnover time (Bronk et al., 2007). The persistence of high DON concentrations in surface oceanic waters has previously been understood to mean that it is unavailable for the marine biota. However, the determination of DON concentrations is subject to high analytical uncertainties (Czerny et al., 2013) that may hide low but ecologically relevant changes in concentrations resulting from the consumption of the labile or semi-labile fraction of the DON pool. Furthermore, due to the heterogeneous composition of DON, isotopic labeling experiments using tracers are difficult to conduct, which explains the lack of information on the fluxes transiting in and out of the DON pool (Bronk, 2002; Bronk et al., 2007). Although heterotrophic bacteria are presumably the main users of this organic pool, it has been shown that primary producers can also use it to meet their N requirements (Antia et al., 1991; Berman and Bronk, 2003). Similarly to fixed $N_{2}$, the fate of DON assimilated by marine plankton will depend on the consumers, whether they would remineralize or export the particulate organic matter produced.

Studying the fate of $\mathrm{N}$ in the ocean is complex as it requires one to follow the biogeochemical characteristics, the succession of planktonic species and the potential export from the same water mass for several weeks. In the open ocean, such studies are further complicated by physical processes (e.g., lateral advection) that spread the water masses. Here, we isolated a part of the water column from physical dispersion using in situ large mesocosms $\left(52 \mathrm{~m}^{3}\right)$ equipped with sediment traps in order to overcome this issue. The objectives of this study were (1) to investigate the contribution of $\mathrm{N}_{2}$ fixation and DON use on PP and particle export, and (2) to trace the fate of these $\mathrm{N}$ sources in the ecosystem, i.e., whether the freshly produced particulate organic $\mathrm{N}(\mathrm{PON})$ is accumulated or exported out of the system.

The mesocosms were deployed in the subtropical New Caledonian lagoon (southwest Pacific), characterized by LNLC conditions (Fichez et al., 2010), where high $\mathrm{N}_{2}$ fixation rates and abundances of Trichodesmium spp. and UCYN communities have been reported (Biegala and Raimbault, 2008; Garcia et al., 2007; Rodier and Le Borgne, 2008, 2010). Phosphate $\left(\mathrm{PO}_{4}^{3-}\right)$ availability has previously been reported to control $\mathrm{N}_{2}$ fixation in the southwest Pacific (Moutin et al., 2005, 2008). In order to avoid $\mathrm{PO}_{4}^{3-}$ limitation and to create favorable conditions for diazotroph growth, the mesocosms were fertilized with $\mathrm{PO}_{4}^{3-}$ at the beginning of the experiment. Diazotrophs developed extensively in the mesocosms during the 23-day experiment (Turk et al., 2015). The diazotroph community was dominated by DDAs during the 
first half of the experiment (from day 5 to day 14, hereafter called P1), then shifted towards a large dominance of UCYN from group C (closely related to Cyanothece sp.), which developed extensively during the second half of the experiment (from day 15 to day 23, hereafter called P2). PP and $\mathrm{N}_{2}$ fixation rates were monitored for the 23 days together with $\mathrm{C}$, $\mathrm{N}$ and $\mathrm{P}$ pools dynamics in the water column and in export material. The results are discussed under the light of the shift of dominance between the two diazotrophic communities.

\section{Material and method}

\subsection{Study site and mesocosm description}

Three mesocosms were deployed at the exit of the oligotrophic New Caledonian lagoon $\left(22^{\circ} 29.1^{\prime} \mathrm{S}-166^{\circ} 26.9^{\prime} \mathrm{E}\right)$, $28 \mathrm{~km}$ off the coast of New Caledonia from 13 January 2013 (day 1) to 4 February 2013 (day 23). The site was $25 \mathrm{~m}$ over a sandy bottom, protected from the dominant trade winds (southeast sector) and characterized by a high influence of oceanic oligotrophic waters coming from outside the lagoon through the Boulari passage (Ouillon et al., 2010). The complete description of the mesocosm design is detailed in Bonnet et al. (2015c). Briefly, the enclosures were cylindrical bags $2.3 \mathrm{~m}$ in diameter and reaching about $15 \mathrm{~m}$ deep into the water. The bags were maintained $1 \mathrm{~m}$ above the surface to prevent external water inclusions. They were supported by a polyethylene frame and kept at the surface with floats. The bags were straightened by weights at the bottom of the mesocosms. After deployment, the mesocosms were left opened at the bottom for $24 \mathrm{~h}$ to ensure a total homogeneity in the water column. On day 1 , the bottom was closed with a sediment trap consisting in a funnel shape end fitted with a 3 in. adapter for fastening a collection bottle for the daily sinking material.

The $\mathrm{PO}_{4}^{3-}$ fertilization was conducted in the evening of day 4. The fertilization consisted of an addition in each mesocosm of $20 \mathrm{~L}$ of a filtered seawater solution enriched with $\mathrm{KH}_{2} \mathrm{PO}_{4}(41.6 \mathrm{mM})$ leading to a final concentration of $\sim 0.8 \mu \mathrm{mol} \mathrm{L}-1$ in the mesocosms. To ensure homogenization, the solution was added to each mesocosm using a polyethylene tubing connected to a Teflon pump lifted regularly from the bottom to the surface of the mesocosms.

\subsection{In situ monitoring and water sampling}

CTD casts and water collection were conducted daily in each of the three replicate mesocosms (hereafter called M1, M2, and M3) and in surrounding waters. Seawater sampling was performed from a floating platform moved around the mesocosms. CTD casts were performed at 10:00 (local time) in each mesocosm and in surrounding waters using a memory probe SBE 911 plus (Sea-Bird Electronics, Inc.) equipped with conductivity, turbidity, fluorimetry, temperature and dissolved oxygen sensors. The CTD was operated at a speed of
$0.2-0.3 \mathrm{~m} \mathrm{~s}^{-1}$. The water was collected just before the CTD casts at three depths in each mesocosm (1, 6 and $12 \mathrm{~m})$ using an air-compressed Teflon pump (AstiPure ${ }^{\mathrm{TM}}$ ) connected to polyethylene tubing. Samples for particulate and dissolved organic and inorganic matter $(\mathrm{C}, \mathrm{N}$ and $\mathrm{P})$ were first collected in $50 \mathrm{~L}$ polypropylene carboys at the three depths and subsampled back on the R/V Alis, moored 1 nautical mile away from the mesocosm site. Samples for $\mathrm{N}_{2}$ fixation rate and PP determination were directly collected from the pump in polycarbonate bottles $(4.5 \mathrm{~L})$ for each depth in each mesocosm and in surrounding waters. Sinking material was collected every day by divers from sediment traps as described in Bonnet et al. (2015c).

\subsection{Primary production rates and phosphate turnover time}

$\mathrm{PP}$ rates and $\mathrm{PO}_{4}^{3-}$ turnover time $\left(T_{\mathrm{PO}_{4}}\right.$, i.e., the ratio of $\mathrm{PO}_{4}^{3-}$ concentration and uptake) were measured using the ${ }^{14} \mathrm{C} /{ }^{33} \mathrm{P}$ dual labeling method (Duhamel et al., 2006). $60 \mathrm{~mL}$ bottles were amended with ${ }^{33} \mathrm{P}$ and ${ }^{14} \mathrm{C}$ and incubated for 3 to $4 \mathrm{~h}$ on a mooring line close to the mesocosm site at the sampling depths. Incubations were stopped by adding $50 \mu \mathrm{L}$ of $\mathrm{KH}_{2} \mathrm{PO}_{4}$ solution $\left(10 \mathrm{mmol} \mathrm{L}^{-1}\right)$ in order to reduce to a minimum the ${ }^{33} \mathrm{P}$ assimilation by dilution effect and by keeping them in the dark to stop ${ }^{14} \mathrm{C}$ uptake. Samples were then filtered on $0.2 \mu \mathrm{mol} \mathrm{L}^{-1}$ polycarbonate membrane filters, and placed into scintillation vials with $250 \mu \mathrm{L}$ of $\mathrm{HCl} 0.5 \mathrm{M}$. After $12 \mathrm{~h}, 5 \mathrm{~mL}$ of scintillation liquid (ULTIMA Gold MV, PerkinElmer Inc.) was added to each vial before the first count on a Packard Tri-Carb ${ }^{\circledR}$ 2100TR scintillation counter. The activity of ${ }^{33} \mathrm{P}$ and ${ }^{14} \mathrm{C}$ was separated using a second count made 5 months later taking into account the half-life of ${ }^{33} \mathrm{P}$ of 25.38 days (Duhamel et al., 2006). PP and $T_{\mathrm{PO}_{4}}$ were calculated according to Moutin et al. (2002).

\section{$2.4 \mathrm{~N}_{2}$ fixation rates}

Samples for $\mathrm{N}_{2}$ fixation incubations were collected in $4.5 \mathrm{~L}$ polycarbonate bottles. The latter were amended with ${ }^{15} \mathrm{~N}_{2}$ enriched seawater according to the protocol developed by Mohr et al. (2010). Briefly, the ${ }^{15} \mathrm{~N}_{2}$-enriched seawater was prepared daily from $0.2 \mu \mathrm{molL}^{-1}$ filtered seawater collected from the same site in a $4.5 \mathrm{~L}$ polycarbonate bottle. Seawater was first degassed through a degassing membrane (Membrana, Minimodule ${ }^{\circledR}$, flow rate fixed at $450 \mathrm{~mL} \mathrm{~min}^{-1}$ ) connected to a vacuum pump ( $<200$ mbar absolute pressure) for at least $1 \mathrm{~h}$. It was then tightly closed with no head space with a silicone septum cap and amended with $1 \mathrm{~mL}$ of ${ }^{15} \mathrm{~N}_{2}$ (98.9\% Cambridge isotope) per $100 \mathrm{~mL}$. The bottle was then shaken vigorously and incubated overnight at 3 bars $(20 \mathrm{~m}$ depth) to promote ${ }^{15} \mathrm{~N}_{2}$ dissolution. Incubation bottles were then amended with $1: 20$ (vol: vol) of ${ }^{15} \mathrm{~N}_{2}$-enriched seawater and closed without headspace with silicone septum caps. These bottles were incubated on an in situ mooring line close 
to the mesocosms at the appropriate sampling depths for $24 \mathrm{~h}$. After incubation, $12 \mathrm{~mL}$ of incubated water was sampled in Exetainers ${ }^{\circledR}$ on 10 replicate samples and analyzed using a Membrane Inlet Mass Spectrometer (Kana et al., 1994) to estimate the final enrichment of the ${ }^{15} \mathrm{~N}_{2}$ pool during the incubation. The measured final ${ }^{15} \mathrm{~N} /{ }^{14} \mathrm{~N}$ ratio of the $\mathrm{N}_{2}$ in the incubation bottles was $2.4 \pm 0.2$ atom $\%(n=10)$. Samples were then filtered on combusted $\left(450{ }^{\circ} \mathrm{C}, 4 \mathrm{~h}\right) \mathrm{GF} / \mathrm{F}$ filters and stored at $-20^{\circ} \mathrm{C}$ for the duration of the cruise. Every day, T0 samples were spiked with ${ }^{15} \mathrm{~N}_{2}$ and immediately filtered in order to determine the initial background of ${ }^{15} \mathrm{~N} /{ }^{14} \mathrm{~N}$ ratio of PON for calculation of $\mathrm{N}_{2}$ fixation rates. Filters were then dried at $60^{\circ} \mathrm{C}$ for $24 \mathrm{~h}$ prior to analysis using a mass spectrometer (Delta plus, Thermo Fisher Scientific) coupled with an elemental analyzer (Flash EA, Thermo Fisher Scientific) for PON concentration and PON ${ }^{15} \mathrm{~N}$ enrichment determination. The standard deviation was $0.004 \mu \mathrm{mol}$ for PON and 0.0001 atom $\%$ for the ${ }^{15} \mathrm{~N} /{ }^{14} \mathrm{~N}$ isotopic ratio. The fluxes were defined as significant when ${ }^{15} \mathrm{~N}$ enrichment was higher than 3 times the standard deviation obtained from T0 samples. The fluxes were calculated according to the equation detailed in Montoya et al. (1996). A recent study (Dabundo et al., 2014) reports potential contamination of commercial ${ }^{15} \mathrm{~N}_{2}$ gas stocks with ${ }^{15} \mathrm{~N}$-enriched $\mathrm{NH}_{4}^{+}, \mathrm{NO}_{3}^{-}$and/or nitrite $\left(\mathrm{NO}_{2}^{-}\right)$, and nitrous oxide. The ${ }^{15} \mathrm{~N}_{2}$ Cambridge Isotopes stocks analyzed contained low concentrations of ${ }^{15} \mathrm{~N}$ contaminants, and the potential overestimated $\mathrm{N}_{2}$ fixation rates modeled using this contamination level would range from undetectable to $0.02 \mathrm{nmolNL}^{-1} \mathrm{~d}^{-1}$. These rates are in the lower end of the range of rates measured in this study and we thus considered that this issue did not affect the results reported here.

\subsection{Chlorophyll $a$ and inorganic and organic matter analyses}

Samples for chlorophyll $a$ (Chl $a$ ) concentrations determination were collected by filtering $550 \mathrm{~mL}$ of seawater on GF / F filters. Filters were directly stored in liquid nitrogen. Chl $a$ was extracted in methanol and measured by fluorometry (Herbland et al., 1985).

Samples for total organic carbon (TOC) concentrations were collected in duplicate at only one depth $(6 \mathrm{~m})$ in each mesocosm and in surrounding waters in precombusted $\left(450^{\circ} \mathrm{C}, 4 \mathrm{~h}\right) 12 \mathrm{~mL}$ sealed glassware flasks, acidified with $\mathrm{H}_{3} \mathrm{PO}_{4}$ and stored in the dark at $4{ }^{\circ} \mathrm{C}$ until analysis. Samples were analyzed on a Shimadzu TOC-V analyzer with a typical precision of $2 \mu \mathrm{mol} \mathrm{L}{ }^{-1}$. Samples for particulate organic carbon (POC) concentrations were collected by filtering $2.3 \mathrm{~L}$ of seawater through a precombusted $\left(450^{\circ} \mathrm{C}, 4 \mathrm{~h}\right)$ $\mathrm{GF} / \mathrm{F}$ filter and determined using the combustion method (Strickland and Parsons, 1972) with an EA 2400 CHN analyzer. Filters were not acidified to remove inorganic carbon as it is assumed to be $<10 \%$ of the total particulate $\mathrm{C}$ (Wangersky, 1994). Dissolved organic carbon (DOC) con- centrations were calculated as the difference between TOC and POC concentrations. The DOC precision calculated from the analytical precision of each term according to the error propagation law was $5 \mu \mathrm{mol} \mathrm{L}^{-1}$.

Samples for $\mathrm{NH}_{4}^{+}$were collected in $40 \mathrm{~mL}$ glass vials and analyzed by the fluorescence method according to Holmes et al. (1999) on a trilogy fluorometer (Turner Design). The detection limit was $0.01 \mu \mathrm{molL} \mathrm{L}^{-1}$. Samples for $\mathrm{NO}_{3}^{-}, \mathrm{NO}_{2}^{-}$, $\mathrm{PO}_{4}^{3-}$, total $\mathrm{N}(\mathrm{TN})$ and total $\mathrm{P}(\mathrm{TP})$ concentrations determination were collected in $40 \mathrm{~mL}$ glass bottles and stored at $-20{ }^{\circ} \mathrm{C}$ until analysis. $\mathrm{NO}_{3}^{-}, \mathrm{NO}_{2}^{-}$and $\mathrm{PO}_{4}^{3-}$ concentrations were determined using a segmented flow analyzer according to Aminot and Kérouel (2007). The detection limit was 0.01 and $0.005 \mu \mathrm{mol} \mathrm{L}^{-1}$ for $\mathrm{NO}_{3}^{-}+\mathrm{NO}_{2}^{-}$and $\mathrm{PO}_{4}^{3-}$, respectively. TN and TP concentrations were determined according to the wet oxidation procedure described in Pujo-Pay and Raimbault (1994). The precision was $0.5 \mu \mathrm{mol} \mathrm{L}{ }^{-1}$ and $0.02 \mu \mathrm{mol} \mathrm{L}{ }^{-1}$ for TN and TP, respectively. Samples for PON and particulate organic $\mathrm{P}$ (POP) concentrations were collected by filtering $1.2 \mathrm{~L}$ of water on precombusted $\left(450{ }^{\circ} \mathrm{C}\right.$, $4 \mathrm{~h})$ and acid washed $(\mathrm{HCl}, 10 \%) \mathrm{GF} / \mathrm{F}$ filters and analyzed according to the wet oxidation protocol described in Pujo-Pay and Raimbault (1994) with a precision of 0.06 and $0.007 \mu \mathrm{mol} \mathrm{L}^{-1}$ for PON and POP, respectively. DON concentrations were calculated from $\mathrm{TN}$ concentrations subtracted by $\mathrm{PON}, \mathrm{NO}_{3}^{-}, \mathrm{NO}_{2}^{-}$and $\mathrm{NH}_{4}^{+}$concentrations. Dissolved organic $\mathrm{P}$ (DOP) concentrations were calculated from TP concentrations subtracted by $\mathrm{POP}$ and $\mathrm{PO}_{4}^{3-}$ concentrations. The precision calculated according to the propagation law of analytical precision associated with each parameter was 0.5 and $0.03 \mu \mathrm{mol} \mathrm{L}{ }^{-1}$ for DON and DOP, respectively.

Samples from sediment traps were collected daily and preserved in a $5 \%$ buffered solution of formaldehyde and stored at $4{ }^{\circ} \mathrm{C}$ until analysis. All the swimmers were handpicked from each sample, and were found to be a negligible source of particulate matter compared to the total particulate matter exported $(<5 \%)$. Samples were then desalted using ultrapure water (Milli-Q grade) and freeze dried. The daily amount of POC exported ( POC $_{\text {export }}$ ) and PON exported $\left(\mathrm{PON}_{\text {export }}\right)$ were measured using a $\mathrm{CHN}$ analyzer (Perkin Elmer 2400). The POP exported ( $\mathrm{POP}_{\text {export }}$ ) was measured after mineralization using nitric acid and further determination of mineralized $\mathrm{P}$ according to Pujo-Pay and Raimbault (1994).

\subsection{Data presentation and statistical analyses}

The build-up of an elemental mass balanced budget is theoretically accessible as all the stocks and fluxes were sampled in the mesocosms. However, the attempts of closing a elemental mass budget in similar mesocosm studies were limited by the large analytical uncertainties on the organic pool determination (Czerny et al., 2013; Guieu et al., 2014). Nevertheless, as the only incoming ( $\mathrm{N}_{2}$ fixation) and export fluxes ( $\mathrm{PON}_{\text {export }}$ ) of $\mathrm{N}$ were characterized accurately, we 
were able to calculate the change in $\mathrm{TN}$ content $\left(\Delta \mathrm{TN}_{\mathrm{calc}}\right)$ of a mesocosm. It was defined as the following:

$\Delta \mathrm{TN}_{\text {calc }}=\Sigma \mathrm{N}_{2, \mathrm{fix}}+\Sigma \mathrm{PON} \mathrm{N}_{\text {export }}$

where $\Sigma \mathrm{N}_{2, \text { fix }}$ and $\Sigma P O N_{\text {export }}$ are the cumulated average over depth $\mathrm{N}_{2}$ fixation rates and $\mathrm{PON}_{\text {export }}$. This approach does not discriminate among the different $\mathrm{N}$ pools in the water column but allows a precise evaluation of the $\mathrm{TN}$ variation in the mesocosm and a direct comparison of the $\mathrm{N}_{2}$ fixation and the $\mathrm{PON}_{\text {export }}$.

The values of fluxes and concentrations presented in the text are averaged over the three depths (no significant differences were observed among depths, paired Friedman test, $\alpha=0.05$ ). Statistical differences between each mesocosm or between the mesocosms and surrounding waters were tested using the paired non-parametric Wilcoxon signed-rank test $(\alpha=0.05)$ for each parameter presented. If no significant differences between the mesocosms were detected, the values were averaged between the mesocosms. The associated uncertainties were calculated as the analytical precision cumulated to the standard deviation of each term according to the propagation of errors law. Differences between P1 and P2 were tested using the non-parametric Kruskal-Wallis test $(\alpha=0.05)$.

\section{Results}

\subsection{Hydrological background}

The detailed description of hydrological and inorganic nutrients conditions during the experiment is presented in Bonnet et al. (2015c). Briefly, seawater temperature increased inside the mesocosms and in surrounding waters from 25.5 to $26.7^{\circ} \mathrm{C}$ over the course of the experiment. The water column was well mixed in the mesocosms as temperature and salinity were homogeneous with depth over the course of the experiment. The sum of $\mathrm{NO}_{3}^{-}$and $\mathrm{NO}_{2}^{-}$concentrations averaged over depth in the mesocosms were below $0.04 \mu \mathrm{molL}^{-1}$ the day before the $\mathrm{PO}_{4}^{3-}$ fertilization (day 4) and decreased to $0.01 \mu \mathrm{molL}^{-1}$ towards the end of the experiment. $\mathrm{NH}_{4}^{+}$concentrations were close to the detection limit of $0.01 \mu \mathrm{molL}^{-1}$ from day 1 to day 18 and increased in all the mesocosms up to $0.06 \mu \mathrm{molL}^{-1}$ toward the end of the experiment. Prior to the $\mathrm{PO}_{4}^{3-}$ fertilization, $\mathrm{PO}_{4}^{3-}$ concentrations in the mesocosms ranged from 0.02 to $0.05 \mu \mathrm{mol} \mathrm{L}{ }^{-1}$. The day after the fertilization, $\mathrm{PO}_{4}^{3-}$ concentrations reached $\sim 0.8 \mu \mathrm{mol} \mathrm{L}{ }^{-1}$ in all mesocosms. Then, the concentrations decreased steadily, tending towards initial concentrations $\left(0.02-0.08 \mu \mathrm{molL}^{-1}\right)$ at the end of the experiment. In surrounding waters, $\mathrm{NO}_{3}^{-}$remained below $0.20 \mu \mathrm{mol} \mathrm{L}-1$ and $\mathrm{PO}_{4}^{3-}$ averaged $0.05 \mu \mathrm{mol} \mathrm{L}{ }^{-1}$ throughout the experiment.
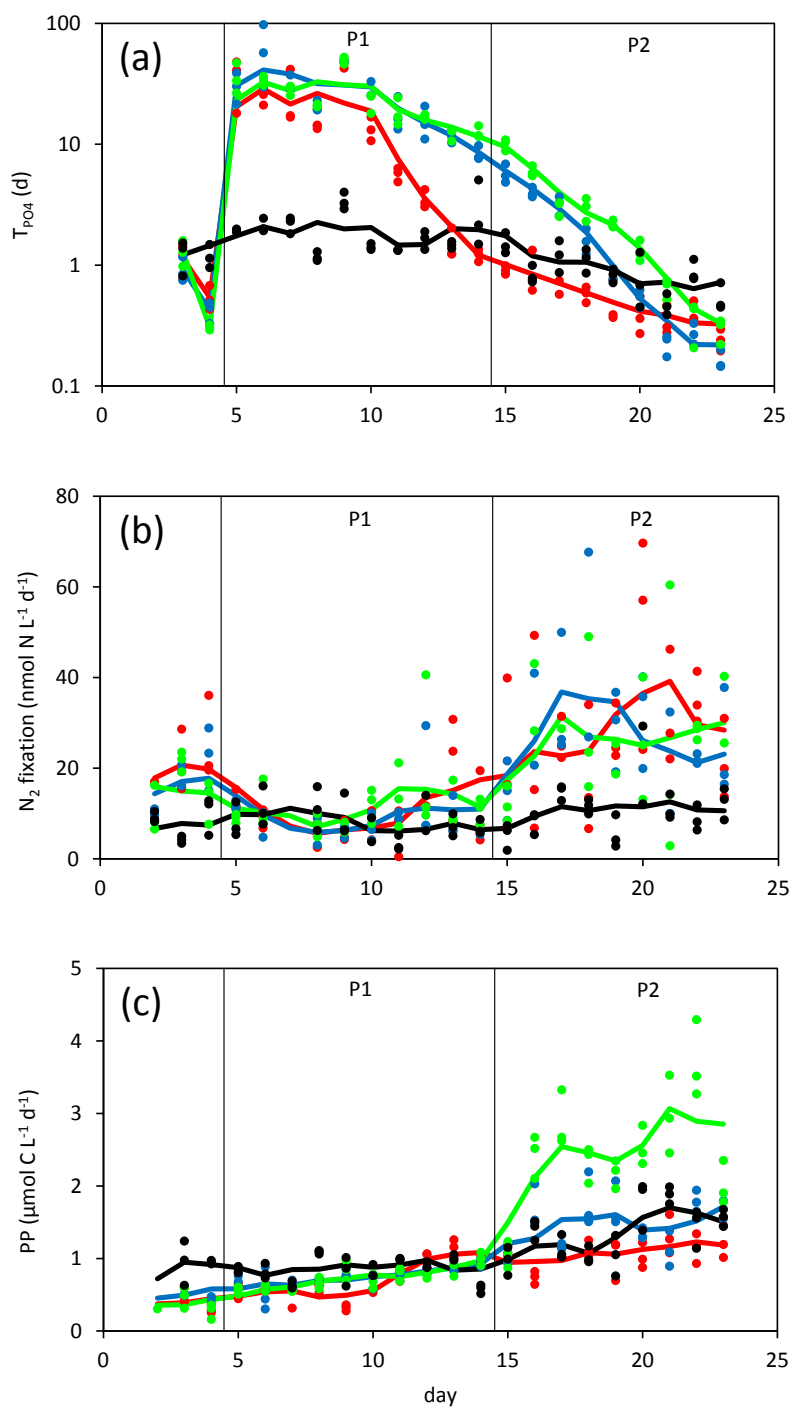

Figure 1. Temporal evolution of (a) phosphate turnover time $\left(T_{\mathrm{PO}_{4}}\right.$, days), (b) dinitrogen fixation $\left(\mathrm{N}_{2}\right.$ fixation) rates $\left(\mathrm{nmolNL}^{-1} \mathrm{~d}^{-1}\right)$ and (c) primary production (PP) rates $\left(\mu \mathrm{molCL} \mathrm{C}^{-1} \mathrm{~d}^{-1}\right)$ in the mesocosms M1 (red), M2 (blue) and M3 (green) and in surrounding waters (black). The three dots of each color represent the measured values at the three sampled depths. The solid lines are the 3-day running mean value. P1 and P2 denote the two phases of the experiment when the diazotrophic community was dominated by diatom-diazotroph associations and unicellular $\mathrm{N}_{2}$-fixing cyanobacteria (group C), respectively.

\subsection{Phosphate turnover time}

The evolution of $T_{\mathrm{PO}_{4}}$ was closely related to the dynamics of $\mathrm{PO}_{4}^{3-}$ concentrations. Before the $\mathrm{PO}_{4}^{3-}$ fertilization, $T_{\mathrm{PO}_{4}}$ decreased from $1.0 \pm 0.1 \mathrm{~d}$ on day 3 to $0.4 \pm 0.1 \mathrm{~d}$ on day 4 in all the mesocosms (Fig. 1a). At the start of $\mathrm{P} 1, T_{\mathrm{PO}_{4}}$ dramatically increased in all mesocosms, reaching $35.7 \pm 15.7$, $30.1 \pm 8.6$ and $35.8 \pm 10.5 \mathrm{~d}$ in M1, M2 and M3, respectively. $T_{\mathrm{PO}_{4}}$ then decreased steadily in all the mesocosms, reaching 
$1 \mathrm{~d}$ on day 14, day 19 and day 21 in M1, M2 and M3, respectively. At the end of the experiment (day 23), $T_{\mathrm{PO}_{4}}$ values were the lowest reached over the entire experiment in all the mesocosms with values below $0.2 \mathrm{~d}$. In surrounding waters, $T_{\mathrm{PO}_{4}}$ was stable around $1.8 \pm 0.7 \mathrm{~d}$ from the start of the experiment to day 15 and then decreased to reach $0.5 \pm 0.1 \mathrm{~d}$ on day 23 (Fig. 1a).

\section{3 $\quad \mathrm{N}_{2}$ fixation and primary production rates}

Before the $\mathrm{PO}_{4}^{3-}$ fertilization, $\mathrm{N}_{2}$ fixation rates inside the mesocosms were $17.4 \pm 7.3 \mathrm{nmolNL}^{-1} \mathrm{~d}^{-1}$ and decreased in the days following the fertilization (Fig. 1b). During $\mathrm{P} 1$, the average $\mathrm{N}_{2}$ fixation rates in the mesocosms were $9.8 \pm 4.0 \mathrm{nmolNL}^{-1} \mathrm{~d}^{-1}$. During $\mathrm{P} 2, \mathrm{~N}_{2}$ fixation rates in the mesocosms were significantly $(p<0.05)$ higher than during $\mathrm{P} 1$, averaging $27.7 \pm 8.6 \mathrm{nmolNL}^{-1} \mathrm{~d}^{-1}$. $\mathrm{N}_{2}$ fixation rates were not significantly different $(p>0.05)$ among the three mesocosms throughout the experiment. In surrounding waters, $\mathrm{N}_{2}$ fixation rates did not show any clear pattern along the experiment and averaged $9.2 \mathrm{nmolNL}^{-1} \mathrm{~d}^{-1}$, ranging from 1.9 to $29.3 \mathrm{nmolNL}^{-1} \mathrm{~d}^{-1}$ (Fig. 1b).

The day before the $\mathrm{PO}_{4}^{3-}$ fertilization, $\mathrm{PP}$ was not significantly different $(p>0.05)$ among the three mesocosms and averaged $0.4 \pm 0.1 \mu \mathrm{molCL} \mathrm{C}^{-1} \mathrm{~d}^{-1}$ (Fig. 1c). During P1, $\mathrm{PP}$ increased steadily in the mesocosms to reach $0.9 \pm$ $0.1 \mu$ mol CL ${ }^{-1} \mathrm{~d}^{-1}$ at the end of P1. During P2, while $T_{\mathrm{PO}_{4}}$ was decreasing, PP continued to increase in the mesocosms with values generally exceeding $1.5 \mu \mathrm{molCL}^{-1} \mathrm{~d}^{-1}$. During $\mathrm{P} 2$, PP was significantly higher in M3 than in M1 and M2 $(p<0.05)$. In surrounding waters, PP was stable before and during $\mathrm{P} 1$ at $0.9 \pm 0.3 \mu \mathrm{mol} \mathrm{CL} \mathrm{C}^{-1} \mathrm{~d}^{-1}$ and increased during $\mathrm{P} 2$ reaching $1.5 \pm 0.2 \mu \mathrm{molCL} \mathrm{CL}^{-1} \mathrm{~d}^{-1}$ on day 23 . Over the whole experiment, PP in the mesocosms was not significantly different from surrounding waters $(p>0.05)$ except in M3 during P2 $(p<0.05)$. Assuming that all the diazotrophs are primary producers and have a $\mathrm{C}: \mathrm{N}$ fixation ratio of 6.6 (Redfield, 1934), we calculated that $\mathrm{N}_{2}$ fixation contributed $10.8 \pm 5.0 \%$ (range 3.7-32.2\%) of PP in the mesocosms after the $\mathrm{PO}_{4}^{3-}$ fertilization and 5.7 $\pm 2.0 \%$ (range 2.2$9.1 \%$ ) in surrounding waters. The contribution of $\mathrm{N}_{2}$ fixation to PP was not significantly different $(p>0.05, n=57)$ during $\mathrm{P} 1(9.0 \pm 3.3 \%)$ and $\mathrm{P} 2(12.6 \pm 6.1 \%)$.

\subsection{Chl $a$ and particulate organic matter dynamics}

The day before the fertilization, Chl $a$ concentrations in the mesocosms were $0.21 \pm 0.05 \mu \mathrm{gL}^{-1}$ (Fig. 2). During P1, Chl $a$ did not show any clear pattern; concentrations were in the 0.12 to $0.28 \mu \mathrm{gL}^{-1}$ range. During $\mathrm{P} 2, \mathrm{Chl} a$ increased in all the mesocosms but to a greater extent in M3 compared to M1 and M2 and reached maximal depth-averaged concentrations of $0.55 \pm 0.01,0.47 \pm 0.08$ and $1.29 \pm 0.22 \mu \mathrm{g} \mathrm{L}^{-1}$ in M1, M2 and M3, respectively. Before and during P1, Chl $a$ concentrations in surrounding waters were close to the con-

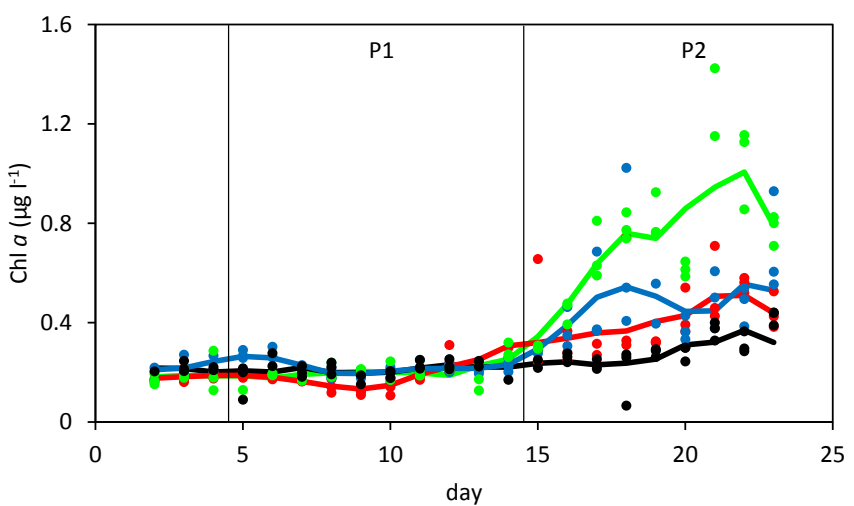

Figure 2. Temporal evolution of chlorophyll $a(\mathrm{Chl} a)$ concentrations $\left(\mu \mathrm{g} \mathrm{L}^{-1}\right)$ in the mesocosms and surrounding waters. The color code is identical to that in Fig. 1. The three dots of each color represent the measured values at the three sampled depths. The solid lines are the 3-day running mean value. P1 and P2 denote the two phases of the experiment when the diazotrophic community was dominated by diatom-diazotroph associations and unicellular $\mathrm{N}_{2}$ fixing cyanobacteria (group C), respectively.

centrations in the mesocosms and ranged between 0.09 and $0.28 \mu \mathrm{g} \mathrm{L}^{-1}$. During P2, they increased but to a lower extent than in the mesocosms with daily averaged concentrations of $0.42 \pm 0.03 \mu \mathrm{g} \mathrm{L}^{-1}$ on day 23 .

The day before the $\mathrm{PO}_{4}^{3-}$ fertilization, POC concentrations ranged from 9 to $15 \mu \mathrm{molL}^{-1}$ (Fig. 3a). During P1, POC concentrations did not show any clear pattern in the mesocosms, and concentrations ranged from 6 to $13 \mu \mathrm{molL} \mathrm{L}^{-1}$. During P2, POC concentrations increased in M3 reaching $18 \mu \mathrm{mol} \mathrm{L}^{-1}$ on day 21 , whereas they remained stable in M1 and M2. POC concentrations in surrounding waters were stable throughout the experiment and were significantly lower $(p<0.05)$ than in the mesocosms. Initial PON concentrations were about $0.9 \mu \mathrm{mol} \mathrm{L} \mathrm{L}^{-1}$ and remained relatively stable during P1 (Fig. 3b). During P2, PON concentrations increased in all the mesocosms by a factor 1.5 in M1 and M2, and by a factor 2 in $\mathrm{M} 3$ at day 23 reaching $2 \mu \mathrm{molL} \mathrm{L}^{-1}$. PON concentrations also increased outside but to a lesser extent with values remaining below $1 \mu \mathrm{molL} \mathrm{L}^{-1}$. POP concentrations showed the same pattern than PON concentrations. The day before the $\mathrm{PO}_{4}^{3-}$ fertilization, POP concentrations were not significantly different $(p>0.05)$ between the mesocosms and averaged $0.05 \mu \mathrm{mol} \mathrm{L}^{-1}$ (Fig. 3c). During $\mathrm{P} 1$, the concentrations in the mesocosms remained relatively stable. During P2, POP concentrations increased in all the mesocosms but to a higher extent in M3, reaching 0.07, 0.07 and $0.12 \mu \mathrm{mol} \mathrm{L}^{-1}$ in M1, M2 and M3, respectively. The particulate POC / PON ratio decreased over the course of the experiment from 12 to 8 , but remained higher than the Redfield ratio (6.6). 

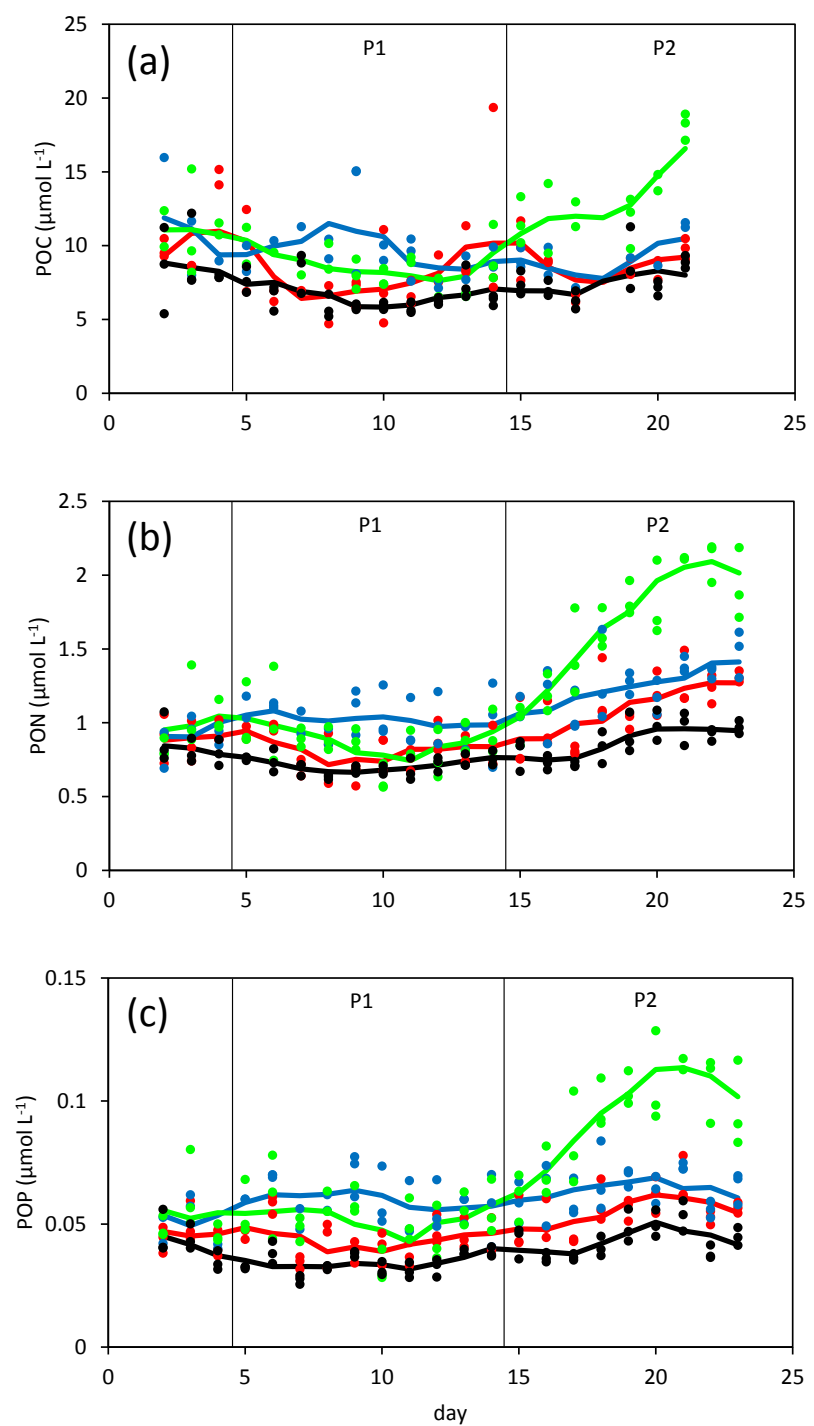

Figure 3. Temporal evolution of (a) particulate organic carbon (POC), (b) particulate organic nitrogen (PON), (c) particulate organic phosphorus (POP) concentrations $\left(\mu \mathrm{mol} \mathrm{L}^{-1}\right)$ in the mesocosms and surrounding waters. The color code is identical to that in Fig. 1. The three dots of each color represent the measured values at the three sampled depths. The solid lines are the 3-day running mean value. P1 and P2 denote the two phases of the experiment when the diazotrophic community was dominated by diatomdiazotroph associations and unicellular $\mathrm{N}_{2}$-fixing cyanobacteria (group C), respectively.

\subsection{Dissolved organic matter dynamics}

DOC concentrations ranged from 50 to $74 \mu \mathrm{molL}^{-1}$ (average value of $60 \pm 4 \mu \mathrm{molL}^{-1}$ ) over the course of the experiment without any clear trend over the 23 days (Fig. 4a). Furthermore, no significant differences were measured between the mesocosms and surrounding waters $(p>0.05)$. Before the $\mathrm{PO}_{4}^{3-}$ fertilization, DON concentrations averaged
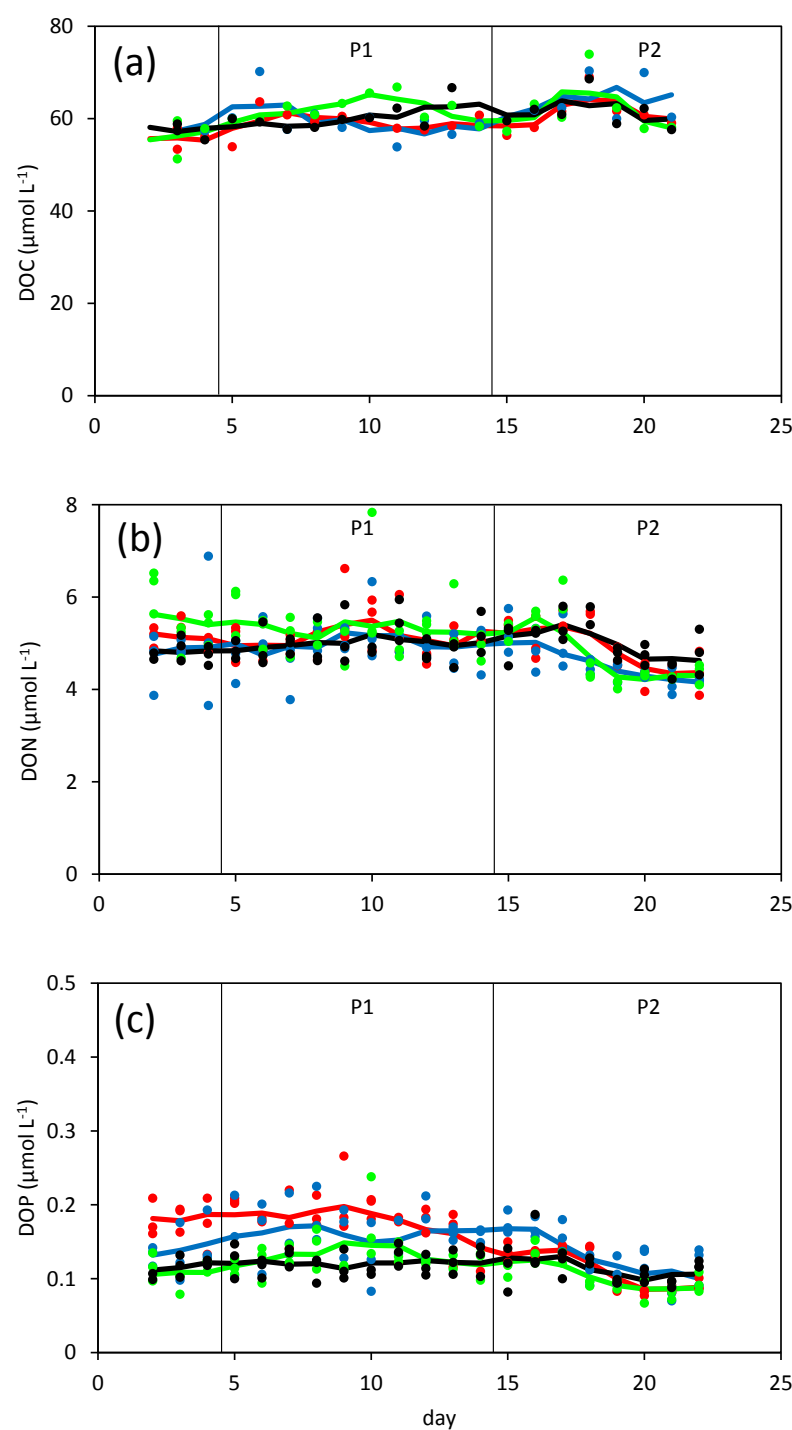

Figure 4. Temporal evolution of (a) dissolved organic carbon (DOC), (b) dissolved organic nitrogen (DON), (c) dissolved organic phosphorus (DOP) concentrations $\left(\mu \mathrm{molL}^{-1}\right)$ in the mesocosms and surrounding waters. The color code is identical to that in Fig. 1. The three dots of each color represent the measured values at the three sampled depths. The solid lines are the 3-day running mean value. P1 and P2 denote the two phases of the experiment when the diazotrophic community was dominated by diatom-diazotroph associations and unicellular $\mathrm{N}_{2}$-fixing cyanobacteria (group $\mathrm{C}$ ), respectively.

$5.2 \pm 0.5 \mu \mathrm{molL} \mathrm{L}^{-1}$ on day 4 (Fig. $4 \mathrm{~b}$ ). Concentrations remained stable during P1 in and out the mesocosms. During P2, DON concentrations decreased significantly $(p<0.05)$ in the three mesocosms. The decrease was $0.7 \pm 0.5,0.8 \pm 0.5$ and $1.0 \pm 0.5 \mu \mathrm{molL}^{-1}$ between day 17 and day 23 in $\mathrm{M} 1$, M2 and M3, respectively, and was not significantly different between the mesocosms $(p>0.05)$. DON concentrations were not significantly different in surrounding waters and in 

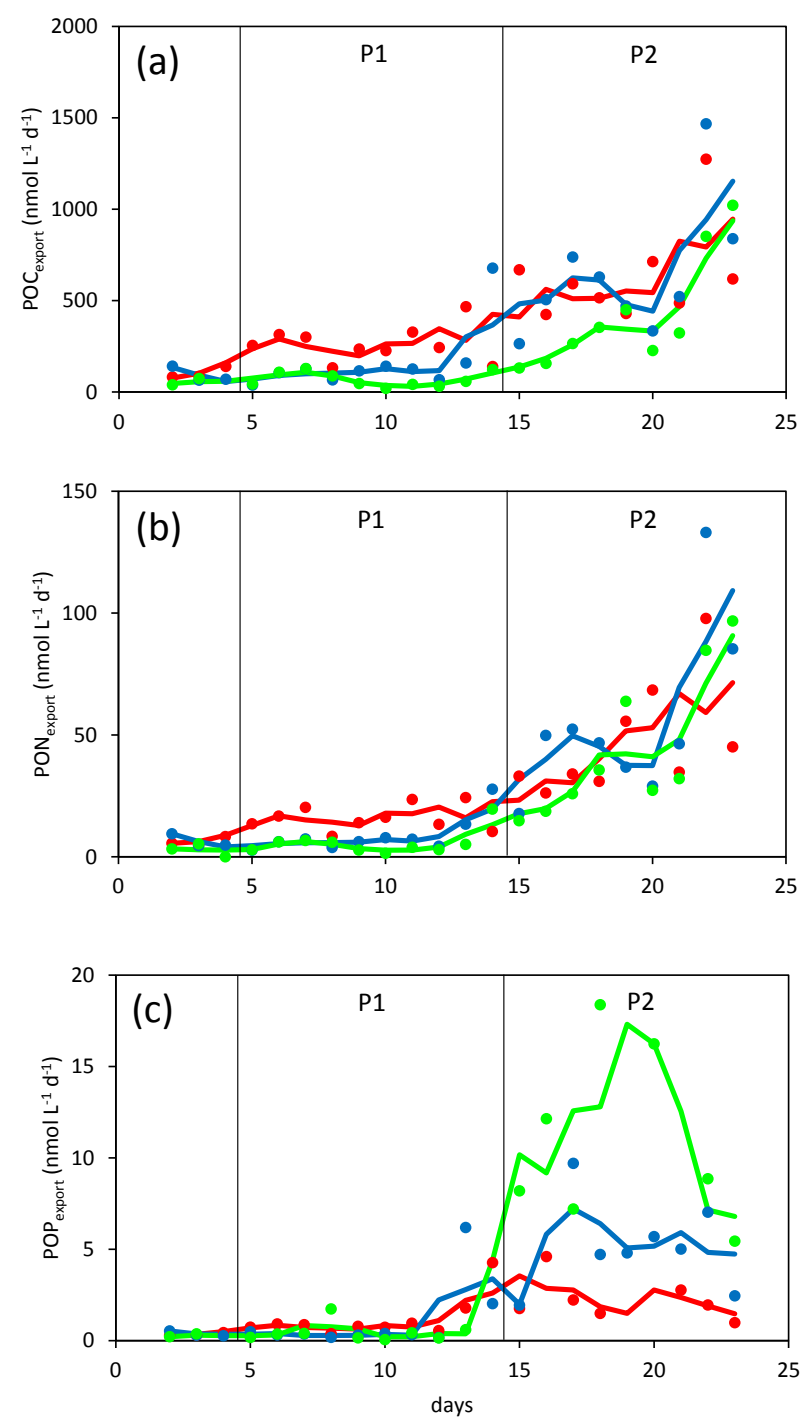

Figure 5. Temporal evolution of (a) particulate organic carbon exported ( $\mathrm{POC}_{\text {export}}$ ), (b) particulate organic nitrogen exported ( $\left.\mathrm{PON}_{\text {export }}\right)$ and (c) particulate organic phosphorus exported

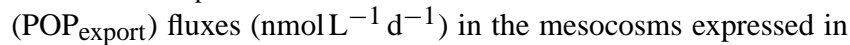
equivalent water volume. The color code is identical to that in Fig. 1. The solid lines are the 3-day running mean value. P1 and P2 denote the two phases of the experiment when the diazotrophic community was dominated by diatom-diazotroph associations and unicellular $\mathrm{N}_{2}$-fixing cyanobacteria (group C), respectively.

the mesocosms up to day 17 ( $p>0.05)$. From this day, even though a significant decrease $(p<0.05)$ in DON concentrations was also observed in surrounding waters, the resulting concentrations were significantly higher outside the mesocosms than inside $(p<0.05)$.

The DOP dynamics was similar to the DON dynamics: during P1, DOP concentrations were on average $0.14 \pm$ $0.03 \mu \mathrm{mol} \mathrm{L}-1$ and remained stable up to day 14 , day 16 and day 17 for M1, M2 and M3, respectively (Fig. 4c). Af- ter these days, DOP concentrations significantly decreased $(p<0.05)$ and reached $0.09 \pm 0.01 \mu \mathrm{molL}^{-1}$ on average. DOP concentrations also decreased in surrounding waters from day 18 , but to a lesser extent than in the mesocosms.

\subsection{Export fluxes and their coupling with primary production and $\mathbf{N}_{2}$ fixation}

Before the $\mathrm{PO}_{4}^{3-}$ fertilization (day 4 ), the exported fluxes were not significantly different $(p>0.05)$ among the three mesocosms $\left(104 \pm 35,6.5 \pm 1.7\right.$ and $0.35 \pm 0.09 \mathrm{nmolL}^{-1} \mathrm{~d}^{-1}$ on average for $\mathrm{POC}_{\text {export }}$, $\mathrm{PON}_{\text {export }}$ and $\mathrm{POP}_{\text {export }}$, respectively) (Fig. 5). The daily exported particulate matter remained relatively stable during P1 averaging $164 \pm$ $141,10.2 \pm 7.1$ and $0.9 \pm 1.3 \mathrm{nmol} \mathrm{L}^{-1} \mathrm{~d}^{-1}$ for $\mathrm{POC}_{\text {export }}$, $\mathrm{PON}_{\text {export }}$ and $\mathrm{POP}_{\text {export }}$, respectively. During P2, the daily export fluxes increased continuously in all the mesocosms to a higher extent than during P1 peaking at $1197 \pm 257$ and $106.1 \pm 20.1 \mathrm{nmolL}^{-1} \mathrm{~d}^{-1}$ for $\mathrm{C}$ and $\mathrm{N}$, respectively. The daily POP export ranged from 1.0 to $18.4 \mathrm{nmol} \mathrm{L}^{-1} \mathrm{~d}^{-1}$.

The $e$ ratio, defined as the amount of exported carbon $\left(\mathrm{POC}_{\text {export }}\right)$ relative to the fixed carbon (PP), was significantly higher $(p<0.05, n=57)$ during $\mathrm{P} 2(39.7 \pm 4.9 \%)$ than during $\mathrm{P} 1(23.9 \pm 20.2 \%)$. Integrated $\mathrm{N}_{2}$ fixation rate over P1 was $0.10 \pm 0.02 \mu \mathrm{mol} \mathrm{L}-1$ on average for all the mesocosms and did not significantly differed from the integrated $\mathrm{PON}_{\text {export }}$ of $0.10 \pm 0.04 \mu \mathrm{molL}^{-1}$ (Fig. 6). The resulting change on the TN pool in the mesocosms remained between -0.01 and $0.01 \mu \mathrm{mol} \mathrm{L}-1$ and was not significantly different from 0 (sign test, $p>0.05$ ). The time-integrated $\mathrm{N}_{2}$ fixation rate over $\mathrm{P} 2$ was $0.25 \pm 0.06 \mu \mathrm{molL}^{-1}$ and the $\mathrm{PON}_{\text {export }}$ was $0.45 \pm 0.04 \mu \mathrm{molL}^{-1}$ (Fig. 6). The resulting change of the $\mathrm{TN}_{\text {calc }}$ pool in the mesocosms remained not significantly different from 0 (sign test, $p>0.05$ ) up to day 18 but deviated negatively from 0 (sign test, $p<0.05$ ) from day 19 to day 23 (Fig. 6). At the end of P2, the decrease of the $\mathrm{TN}_{\text {calc }}$ pool was $0.20 \pm 0.04 \mu \mathrm{molL}^{-1}$.

\section{Discussion}

\subsection{Phosphate availability sustained $\mathrm{N}_{2}$ fixation and in turn new primary production}

$\mathrm{N}_{2}$ fixation is limited by micronutrient availability such as iron (Fe) (Dekaezemacker et al., 2013; Monteiro et al., 2011; Moore et al., 2009; Shiozaki et al., 2014), temperature (Breitbarth et al., 2007; Fu et al., 2014; Mulholland and Bernhardt, 2005), light (Garcia et al., 2013; Kranz et al., 2010) and ultimately by $\mathrm{PO}_{4}^{3-}$ availability (Dore et al., 2008; Karl et al., 1997; Moutin et al., 2008). During this experiment, $\mathrm{PO}_{4}^{3-}$ fertilization was carried out as P limitation would have prevented diazotroph growth. This fertilization, associated with the relatively high micronutrient concentrations (e.g., Fe) (Ambatsian et al., 1997), high seawater temperature $\left(>25^{\circ} \mathrm{C}\right)$ and the maintenance of the water mass 
in the photic layer, provided optimal conditions for diazotroph growth. As expected, diverse diazotroph phylotypes developed extensively in the mesocosms with abundances of $1.10^{5}$ to $5.10^{5}$ nifH copies $\mathrm{L}^{-1}$ (Turk et al., 2015). Furthermore, $\mathrm{N}_{2}$ fixation rates in the mesocosms were high (18.5 \pm $13.1 \mathrm{nmol} \mathrm{NL}^{-1} \mathrm{~d}^{-1}$ ) compared to those in surrounding waters $\left(9.2 \pm 4.8 \mathrm{nmolNL}^{-1} \mathrm{~d}^{-1}\right)$ (Fig. 1b) and are among the highest reported in the literature (Luo et al., 2012).

The contribution of $\mathrm{N}_{2}$ fixation to PP $(10.8 \pm 5.0 \%)$ in the mesocosms and in surrounding waters $(5.7 \pm 2.0 \%)$ was in the upper range of previous studies in the Pacific Ocean (Raimbault and Garcia, 2008; Shiozaki et al., 2013) and the Mediterranean Sea (Bonnet et al., 2011; Ridame et al., 2013). Prior to $\mathrm{PO}_{4}^{3-}$ fertilization, $\mathrm{NO}_{3}^{-}$concentrations were $<0.04 \mu \mathrm{molL}^{-1}$. As there was no external supply of $\mathrm{NO}_{3}^{-}$, the potential consumption of the initial $\mathrm{NO}_{3}^{-}$in the mesocosms represented $<11.5 \%$ of the integrated $\mathrm{N}_{2}$ fixation rates over P1 and P2 $\left(0.35 \pm 0.08 \mu \mathrm{molL}^{-1}\right)$ (Fig. 6). Thus, $\mathrm{N}_{2}$ fixation supplied nearly all of the new production during the experiment. These results indicate that in a $\mathrm{N}$-depleted system, diazotrophs can provide enough new $\mathrm{N}$ to sustain high PP (exceeding $2 \mu \mathrm{molCL}^{-1} \mathrm{~d}^{-1}$ ) and biomass (up to $1.42 \mu \mathrm{gL}^{-1}$ of $\mathrm{Chl} a$ ), as long as $\mathrm{PO}_{4}^{3-}$ does not limit $\mathrm{N}_{2}$ fixation.

\subsection{The relative efficiency of different diazotrophs to export particulate matter}

Only few studies have focused on the direct coupling between $\mathrm{N}_{2}$ fixation and particulate export (Dore et al., 2008; Karl et al., 2012; White et al., 2012). To our knowledge, the only study comparing the export efficiency of different diazotrophs reports that DDAs blooms could contribute up to $44 \%$ of the direct export in the northeast Pacific, while UCYN (Group A) and Trichodesmium spp. could account for only 0 to $10 \%$ of the export (White et al., 2012). The scarcity of data is due to methodological issues associated with the use of sediment traps in the open ocean due to (1) the patchy distribution of $\mathrm{N}_{2}$ fixers that are not necessarily collected by the sediment traps, and (2) the temporal lag between production and export which is difficult to assess (Nodder and Waite, 2001). The mesocosm approach was designed to overcome these experimental limitations. The shallow depth of the traps $(\sim 15 \mathrm{~m})$ and the absence of $\mathrm{NO}_{3}^{-}$ normally supplied via the nitracline prevent any comparison with open ocean studies. Nevertheless, the mesocosm approach enables a comparison of the export efficiency under contrasting ecological situations. In this case, the period dominated by DDAs (P1) is compared with the period dominated by UCYN-C (P2).

During P1, the biomass was stable in the mesocosms and the amount of recently fixed $\mathrm{N}_{2}$ was equal to the amount of exported PON, suggesting a tight coupling between the two processes (Fig. 6). It has been shown that large aggregates of the diatom Rhizosolenia spp., representing the majority of
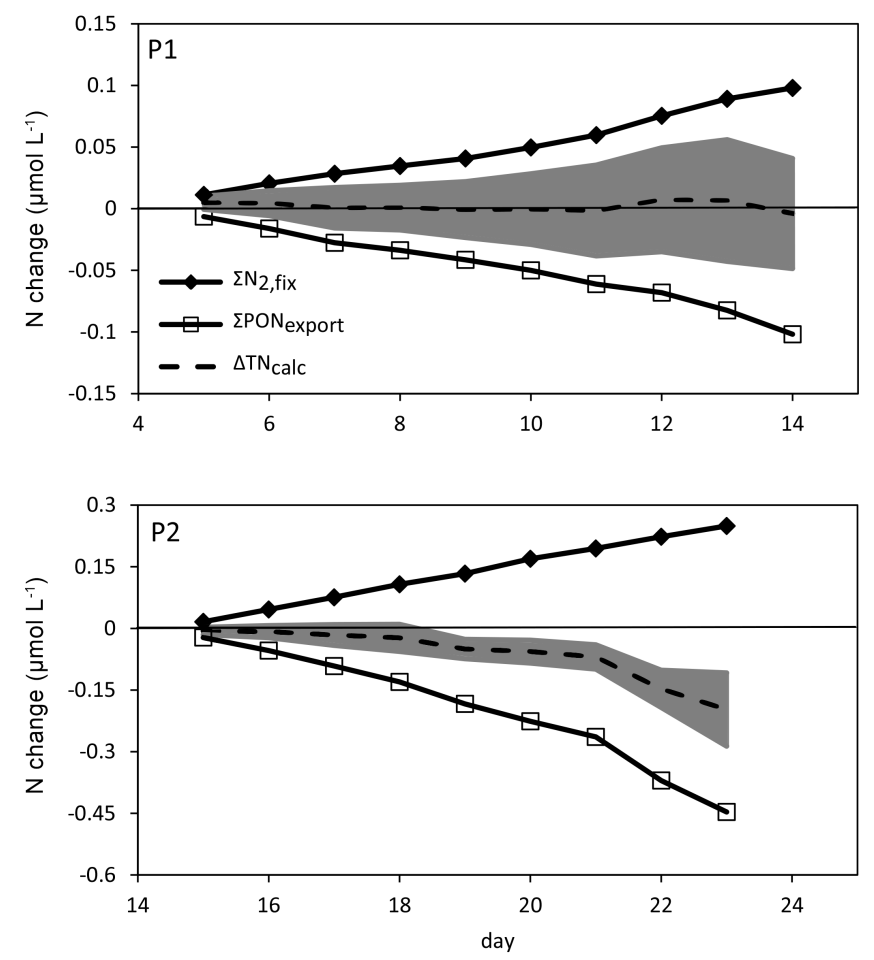

Figure 6. Time-integrated dinitrogen fixation rates $\left(\Sigma \mathrm{N}_{2, \mathrm{fix}}\right)$ and particulate organic nitrogen exported $\left(\Sigma \mathrm{PON}_{\text {export }}\right)$ during P1 (dominance of diatom-diazotroph associations) and P2 (dominance of unicellular $\mathrm{N}_{2}$-fixing cyanobacteria group $\mathrm{C}$ ) in the mesocosms together with the calculated change in Total $\mathrm{N}$ content $\left(\Delta \mathrm{TN}_{\mathrm{calc}}\right)$ defined as the difference between $\Sigma \mathrm{N}_{2 \text {,fix }}$ and $\Sigma$ PON $\mathrm{N}_{\text {export. The }}$ shaded areas represent the uncertainty associated with the $\Delta \mathrm{TN}_{\mathrm{calc}}$ change.

DDAs during P1 (Turk et al., 2015), can sink at high rates (Villareal et al., 1996). This suggests that during this experiment, the recently fixed $\mathrm{N}_{2}$ by DDAs remained within the symbiotic association and was quickly exported in the settling particles. This agrees with Karl et al. (2012), who showed that DDAs support the export pulses regularly observed in late summer in the tropical North Pacific Ocean.

During P2, the increase in PON concentrations (Fig. 3b) suggests that part of the freshly produced biomass remained in the water column. The accumulation of PON probably favored remineralization processes, explaining the increase in $\mathrm{NH}_{4}^{+}$concentrations. This may have enhanced the transfer of the recently fixed $\mathrm{N}_{2}$ to the non-diazotrophic plankton as demonstrated by Bonnet et al. (2015a) and explains the development of picocyanobacteria (Leblanc et al., 2015). Additionally, the total amount of $\mathrm{N}$ provided by $\mathrm{N}_{2}$ fixation did not account for all the exported PON during P2 (Fig. 6), implying that an additional $\mathrm{N}$ source played a significant role in promoting the export. The only alternative $\mathrm{N}$ source is DON which, indeed, exhibited a significant decrease in concentration of $0.9 \pm 0.7 \mu \mathrm{molL}^{-1}$ in the mesocosms during P2 (see Sect. 4.3 for further discussion on DON consumption). 
Assuming that DON and $\mathrm{N}_{2}$ fixation are the only possible sources of $\mathrm{N}$ in the mesocosms, we calculated that a DON use of $0.9 \mu \mathrm{molL}^{-1}$ would have supported $\sim 78 \%$ of the PON production during $\mathrm{P} 2$, and potentially fueled the PON export to the same extent. This is in agreement with TorresValdé et al. (2009) and Letscher et al. (2013), who showed that DON pool is a dynamic contributor of the $\mathrm{N}$ cycle able to support up to $40 \%$ of the vertical PON export in the oligotrophic gyres of the Pacific and Atlantic Oceans. A quantification of the diazotrophs in the sediment traps, performed on day 19 , shows that $\sim 10 \%$ of the UCYN-C biomass in the mesocosms was exported on this day, explaining $\sim 7 \%$ of the PON export (Bonnet et al., 2015a). Thus, the $\mathrm{N}_{2}$ recently fixed by UCYN-C can directly be exported, but is probably more efficiently transferred to non-diazotrophic plankton through mineralization processes.

The contrast between $\mathrm{P} 1$ and $\mathrm{P} 2$ is also observed using the $e$ ratio. The production driven by UCYN-C was more efficient in promoting POC export than the production driven by DDAs. During P1, it is probable that the recently fixed C by DDAs remained within the symbiotic association and sunk with the recently fixed $\mathrm{N}_{2}$ constituting a direct and net $\mathrm{C}$ export. During P2, the higher efficiency of C export strongly suggests that the DON ultimately fueled PP which, in turn, increased POC export. Additionally, when UCYN-C dominated, an enhanced $\mathrm{N}$ remineralization may have enabled more $\mathrm{C}$ to be fixed per unit of fixed $\mathrm{N}_{2}$, leading to a higher $e$ ratio. A proportionally higher $\mathrm{N}$ remineralization following high PP and $\mathrm{N}_{2}$ fixation rates is supported by similar findings in the western North Pacific warm pool (Shiozaki et al., 2013).

\subsection{The unexpected high dissolved organic matter consumption}

The use of dissolved organic compounds and their implications on PP in the open ocean has long been demonstrated (Antia et al., 1991). The use of DOP by plankton communities in the oligotrophic ocean has been observed in the North Pacific Ocean (Bjorkman and Karl, 2003) and in the Atlantic Ocean (Lomas et al., 2010; Mather et al., 2008) and generally occurs under $\mathrm{PO}_{4}^{3-}$ limitation. In this study, the decrease in DOP concentrations during $\mathrm{P} 2$ occurred when $T_{\mathrm{PO}_{4}}$ reached the lowest levels, confirming the ability of the planktonic community to use DOP under low $\mathrm{PO}_{4}^{3-}$ availability. More surprisingly, the significant and rapid decrease in DON concentrations (Fig. 4) observed during the development of UCYN-C (P2) in the mesocosms was associated with a rapid increase in PP (Fig. 1c), biomass (Figs. 2 and 3) and bacterial production (BP) (Van Wambeke et al., 2015), suggesting high consumption of DON directly or indirectly by primary producers. In the open ocean, DON is mainly refractory. Nevertheless, it is now recognized that a fraction of the DON is labile and can directly support phytoplankton growth, while a semi-labile fraction can be mineralized by bacterioplank- ton (Antia et al., 1991; Bronk, 2002; Bronk et al., 2007). In this study, we propose three hypotheses that could explain the observed decrease in DON concentrations during P2: (i) bacterial mineralization of DON triggered by high PP, (ii) direct uptake of DON by primary producers including UCYN$\mathrm{C}$ and (iii) abiotic photo-degradation of DON into $\mathrm{NH}_{4}^{+}$.

i. The increase in PP driven by high $\mathrm{N}_{2}$ fixation rates during P2 led to an increase in bacterial production (Van Wambeke et al., 2015). The significant negative correlation between BP and DON concentrations (Spearman rank correlation, $r=-0.35 ; p<0.001)$ indicate significant consumption of DON by bacterial mineralization. Diazotrophs are known to over-fix $\mathrm{C}$ relative to N (Mulholland et al., 2007), which may explain why the POC/PON ratio was above the Redfield ratio during the experiment. The resulting $\mathrm{N}$ deficit for bacterial mineralization may have been found in the labile or semi-labile DON pool. This hypothesis is supported by Van Wambeke et al. (2015), who showed that BP was limited by $\mathrm{N}$ availability in the mesocosms during the experiment. Based on BP data and assuming a bacterial growth efficiency of 10 to $30 \%$ (del Giorgio and Cole, 1998) and a $\mathrm{C} / \mathrm{N}$ ratio of 6.6 in bacteria cells (Fukuda et al., 1998), bacterial respiration would have led to a DON consumption of 0.2 to $0.7 \mu \mathrm{molL}^{-1}$ during P2, supporting at least part of the DON removal of $\sim 0.9 \mu \mathrm{mol} \mathrm{L}^{-1}$ reported here.

ii. An alternative explanation for the decrease in DON concentrations is direct consumption by primary producers. Cyanobacteria are known to use DON compounds such as urea (Collier et al., 2009; Painter et al., 2008) to such an extent that DON has been reported to be one of the main sources of $\mathrm{N}$ for cyanobacterial blooms in coastal waters (Glibert et al., 2004). The DON decrease occurring during the development of UCYN-C, whose abundances reached $5.10^{5}$ nifH copies $\mathrm{L}^{-1}$ (Turk et al., 2015), questions their ability to use DON to meet their $\mathrm{N}$ requirements. Direct uptake of glutamate and amino acids (constitutive components of the DON pool) has been reported in natural and laboratory populations of Trichodesmium spp. (Mulholland and Capone, 1999; Mulholland et al., 1999). Furthermore, large decrease in DON concentrations were observed after blooms of the diazotroph Aphanizomenon ovalisporum in Lake Kinneret (Berman, 1997). The hypothesis of a direct use of DON by A. ovalisporum was confirmed in a culture experiment where the development of this diazotroph was stimulated by DON additions (Berman, 1997, 1999). To our knowledge, no direct uptake measurements of DON compounds have been performed on UCYN. However, the ure A gene involved in the urea assimilation has been identified in the cyanobacterial diazotrophic strain Cyanothece PCC 7822 (Bandyopadhyay et al., 2011) closely related to the UCYN-C cluster. These pieces 
of evidences suggest that in addition to $\mathrm{N}_{2}$ fixation, UCYN-C might be able to use the DON pool to meet their $\mathrm{N}$ requirements.

iii. Finally, photo-degradation could be a possible sink of DON in surface waters (Bronk, 2002). A field study performed in the ultraoligotrophic eastern basin of the Mediterranean Sea indicates a production of $\mathrm{NH}_{4}^{+}$from DON of $0.2-2.9 \mathrm{nmolNL}^{-1} \mathrm{~d}^{-1}$ in surface waters (Kitidis et al., 2006). Taking into account the highest rates reported above, this process cannot explain more than $10 \%$ of the observed DON removal. Moreover, the DON decrease occurred only during P2 whereas photodegradation would be occurring continuously over the entire experiment.

The first two hypotheses (i and ii) are more likely to explain the DON decrease during P2. Neither of these two hypotheses can be excluded even though direct proof of large uptake of DON by UCYN-C is lacking. Thus, in this study, the DON use was directly or indirectly triggered by the UCYN-C activity.

\section{Conclusions}

This study confirms that, in the southwest Pacific, $\mathrm{N}_{2}$ fixation is a biogeochemically relevant process able to provide sufficient new $\mathrm{N}$ to drive new PP, biomass accumulation and organic matter export as long as $\mathrm{P}$ is not limiting. The fate of the recently fixed $\mathrm{N}$ appears to be closely related to the diazotrophic community involved in $\mathrm{N}_{2}$ fixation. A strong coupling of $\mathrm{N}_{2}$ fixation and PON export occurred when DDAs dominated the diazotrophic community, suggesting their direct export. When the community was dominated by UCYN$\mathrm{C}$, biomass accumulation was observed together with an efficient particulate export. A significant decrease in DON concentrations was observed during the same period indicating a direct or indirect use of DON by UCYN-C. Thus, in addition to fueling primary production, UCYN-C appear to be able to enhance regenerated production based both on the transfer of recently fixed $\mathrm{N}_{2}$ toward non-fixing planktonic groups and on the use of the DON pool. This use of DON exceeded the new $\mathrm{N}$ provided by $\mathrm{N}_{2}$ fixation even though the $\mathrm{N}_{2}$ fixation rates were among the highest reported in literature for the global ocean. These results suggest that DON has to be considered as a dynamic pool in LNLC areas as it may provide significant amounts of $\mathrm{N}$ and contribute significantly to particulate export.

Acknowledgements. Funding for this research was provided by the Agence Nationale de la Recherche (ANR starting grant VAHINE ANR-13-JS06-0002), the INSU-LEFE-CYBER program, GOPS and IRD. The Ph.D. scholarship for H. Berthelot came from the French Ministry of Research and Education. The authors thank the captain and crew of the R/V Alis. We acknowledge the SEOH diver service from Noumea as well as the technical service of the IRD research center of Noumea for their helpful technical support together with C. Guieu, J.-M. Grisoni and F. Louis for mesocosm design and the useful advice. We are also grateful to the two reviewers and T. Lefevre, who greatly improved the manuscript.

Edited by: E. Marañón

\section{References}

Ambatsian, P., Fernex, F., Bernat, M., Parron, C., and Lecolle, J.: High metal inputs to closed seas: the New Caledonian lagoon, J. Geochem. Explor., 59, 59-74, doi:10.1016/S03756742(96)00020-9, 1997.

Aminot, A. and Kérouel, R.: Dosage automatique des nutriments dans les eaux marines, Ifremer, Plouzané, 2007

Antia, N. J., Harrison, P. J., and Oliveira, L.: The role of dissolved organic nitrogen in phytoplankton nutrition, cell biology and ecology, Phycologia, 30, 1-89, doi:10.2216/i0031-8884-301-1.1, 1991.

Bandyopadhyay, A., Elvitigala, T., Welsh, E., Stöckel, J., Liberton, M., Min, H., Sherman, L. A., and Pakrasi, H. B.: Novel metabolic attributes of the genus Cyanothece, comprising a group of unicellular nitrogen-fixing Cyanothece, MBio, 2, 5, doi:10.1128/mBio.00214-11, 2011.

Berman, T.: Dissolved organic nitrogen utilization by an Aphanizomenon bloom in Lake Kinneret, J. Plankton Res., 19, 577-586, doi:10.1093/plankt/19.5.577, 1997.

Berman, T.: Algal growth on organic compounds as nitrogen sources, J. Plankton Res., 21, 1423-1437, doi:10.1093/plankt/21.8.1423, 1999.

Berman, T. and Bronk, D. A.: Dissolved organic nitrogen: a dynamic participant in aquatic ecosystems, Aquat. Microb. Ecol., 31, 279-305, doi:10.3354/ame031279, 2003.

Biegala, I. and Raimbault, P.: High abundance of diazotrophic picocyanobacteria $\left(<3 \mu \mathrm{mol} \mathrm{L}{ }^{-1}\right)$ in a Southwest Pacific coral lagoon, Aquat. Microb. Ecol., 51, 45-53, doi:10.3354/ame01185, 2008.

Bjorkman, K. and Karl, D.: Bioavailability of dissolved organic phosphorus in the euphotic zone at Station ALOHA, North Pacific Subtropical Gyre, Limnol. Oceanogr., 48, 1049-1057, doi:10.4319/1o.2003.48.3.1049, 2003.

Bonnet, S., Grosso, O., and Moutin, T.: Planktonic dinitrogen fixation along a longitudinal gradient across the Mediterranean Sea during the stratified period (BOUM cruise), Biogeosciences, 8 , 2257-2267, doi:10.5194/bg-8-2257-2011, 2011.

Bonnet, S., Berthelot, H., Grisoni, J.-M., Fawcett, S. E., Van Wambeke, F., Cornet-Bartaux, V., Helias, S., Grosso, O., Rahav, E., Berman-Frank, I., Leblond, N., Moutin, T., and L'Helguen, S.: Dinitrogen fixation and fate of diazotroph-derived nitrogen during the VAHINE mesocosm experiment, in preparation, 2015a.

Bonnet, S., Berthelot, H., Turk-Kubo, K., Cornet-Bartaux, V., Fawcett, S. E., Berman-Frank, I., Barani, A., Dekaezemacker, J., Benavides, M., Charriere, B., and Capone, D. G.: Diazotroph derived nitrogen supports diatom growth in the South West Pacific: a quantitative study using nanoSIMS, in review, 2015 b. 
Bonnet, S., Grisoni, J.-M., Moutin, T., Folcher, E., Bourgeois, B., and Renaud, A.: Introduction to the VAHINE project: VAriability of vertical and tropHIc transfer of fixed $\mathrm{N}_{2}$ in the south wEst Pacific, in preparation, 2015c.

Breitbarth, E., Oschlies, A., and LaRoche, J.: Physiological constraints on the global distribution of Trichodesmium - effect of temperature on diazotrophy, Biogeosciences, 4, 53-61, doi:10.5194/bg-4-53-2007, 2007.

Bronk, D. A.: Dynamics of DON, in: Biogeochemistry of Marine Dissolved Organic Matter, edited by: Hansell, D. A. and Carlson, C. A., Academic press, San Diego, 153-247, 2002.

Bronk, D. A., See, J. H., Bradley, P., and Killberg, L.: DON as a source of bioavailable nitrogen for phytoplankton, Biogeosciences, 4, 283-296, doi:10.5194/bg-4-283-2007, 2007.

Capone, D. G., Zehr, J. P., Paerl, H. W., Bergman, B., and Carpenter, E. J.: Trichodesmium, a globally significant marine cyanobacterium, Science, 276, 1221-1229, doi:10.1126/science.276.5316.1221, 1997.

Chen, Y., Chen, H., and Lin, Y.: Distribution and downward flux of Trichodesmium in the South China Sea as influenced by the transport from the Kuroshio Curren, Mar. Ecol.-Prog. Ser., 259, 47-57, doi:10.3354/meps259047, 2003.

Collier, J. L., Baker, K. M., and Bell, S. L.: Diversity of urea-degrading microorganisms in open-ocean and estuarine planktonic communities., Environ. Microbiol., 11, 3118-3131, doi:10.1111/j.1462-2920.2009.02016.x, 2009.

Czerny, J., Schulz, K. G., Boxhammer, T., Bellerby, R. G. J., Büdenbender, J., Engel, A., Krug, S. A., Ludwig, A., Nachtigall, K., Nondal, G., Niehoff, B., Silyakova, A., and Riebesell, U.: Implications of elevated $\mathrm{CO}_{2}$ on pelagic carbon fluxes in an Arctic mesocosm study - an elemental mass balance approach, Biogeosciences, 10, 3109-3125, doi:10.5194/bg-10-3109-2013, 2013.

Dabundo, R., Lehmann, M. F., Treibergs, L., Tobias, C. R., Altabet, M. A., Moisander, P. H., and Granger, J.: The contamination of commercial ${ }^{15} \mathrm{~N}_{2}$ gas stocks with ${ }^{15} \mathrm{~N}$-labeled nitrate and ammonium and consequences for nitrogen fixation measurements, PLoS One, 9, e110335, doi:10.1371/journal.pone.0110335, 2014.

Dekaezemacker, J., Bonnet, S., Grosso, O., Moutin, T., Bressac, M., and Capone, D. G.: Evidence of active dinitrogen fixation in surface waters of the eastern tropical South Pacific during El Niño and La Niña events and evaluation of its potential nutrient controls, Global Biogeochem. Cy., 27, 768-779, doi:10.1002/gbc.20063, 2013.

Del Giorgio, P. A. and Cole, J. J.: Bacterial growth efficiency in natural aquatic systems, Annu. Rev. Ecol. Syst., 29, 503-541, doi:10.1146/annurev.ecolsys.29.1.503, 1998.

Dore, J. E., Letelier, R. M., Church, M. J., Lukas, R., and Karl, D. M.: Summer phytoplankton blooms in the oligotrophic North Pacific Subtropical Gyre: historical perspective and recent observations, Prog. Oceanogr., 76, 2-38, doi:10.1016/j.pocean.2007.10.002, 2008 .

Dugdale, R. C. and Goering, J. J.: Uptake of new and regenerated forms of nitrogen in primary productivity, Limnol. Oceanogr., 12, 196-206, doi:10.4319/lo.1967.12.2.0196, 1967.

Duhamel, S., Zeman, F., and Moutin, T.: A dual labelling method for the simultaneous measurement of dissolved inorganic carbon and phosphate uptake by marine planktonic species, Lim- nol. Oceanogr.-Meth., 4, 416-425, doi:10.4319/lom.2006.4.416, 2006.

Fichez, R., Chifflet, S., Douillet, P., Gérard, P., Gutierrez, F., Jouon, A., Ouillon, S., and Grenz, C.: Biogeochemical typology and temporal variability of lagoon waters in a coral reef ecosystem subject to terrigeneous and anthropogenic inputs (New Caledonia), Mar. Pollut. Bull., 61, 309-322, doi:10.1016/j.marpolbul.2010.06.021, 2010.

Fu, F., Yu, E., Garcia, N., Gale, J., Luo, Y., Webb, E., and Hutchins, D.: Differing responses of marine $\mathrm{N}_{2}$ fixers to warming and consequences for future diazotroph community structure, Aquat. Microb. Ecol., 72, 33-46, doi:10.3354/ame01683, 2014.

Fukuda, R., Ogawa, H., Nagata, T., and Koike, I.: Direct determination of carbon and nitrogen contents of natural bacterial assemblages in marine environments, Appl. Environ. Microb., 64 3352-3358, 1998.

Garcia, N., Raimbault, P., and Sandroni, V.: Seasonal nitrogen fixation and primary production in the Southwest $\mathrm{Pa}$ cific: nanoplankton diazotrophy and transfer of nitrogen to picoplankton organisms, Mar. Ecol.-Prog. Ser., 343, 25-33, doi:10.3354/meps06882, 2007.

Garcia, N. S., Fua, F. X., Breene, C. L., Yu, E. K., Bernhardt, P. W., Mulholland, M. R., and Hutchins, D. A.: Combined effects of $\mathrm{CO}_{2}$ and light on large and small isolates of the unicellular $\mathrm{N}_{2}-$ fixing cyanobacterium Crocosphaera watsonii from the western tropical Atlantic Ocean, Eur. J. Phycol., 48, 128-139, 2013.

Glibert, P. M., Heil, C. A., Hollander, D., Revilla, M., Hoare, A., Alexander, J., and Murasko, S.: Evidence for dissolved organic nitrogen and phosphorus uptake during a cyanobacterial bloom in Florida Bay, Mar. Ecol.-Prog. Ser., 280, 73-83, doi:10.3354/meps280073, 2004.

Gruber, N. and Galloway, J. N.: An Earth-system perspective of the global nitrogen cycle, Nature, 451, 293-296, doi:10.1038/nature06592, 2008.

Guieu, C., Ridame, C., Pulido-Villena, E., Bressac, M., Desboeufs, K., and Dulac, F.: Impact of dust deposition on carbon budget: a tentative assessment from a mesocosm approach, Biogeosciences, 11, 5621-5635, doi:10.5194/bg-11-5621-2014, 2014.

Herbland, A., Le Bouteiller, A., and Raimbault, P.: Size structure of phytoplankton biomass in the equatorial Atlantic Ocean, Deep-Sea Res., 32, 819-836, doi:10.1016/0198-0149(85)901189, 1985

Holmes, R. M., Aminot, A., Kérouel, R., Hooker, B. and Peterson, B. J.: A simple and precise method for measuring ammonium in marine and freshwater ecosystems, Can. J. Fish. Aquat. Sci., 56, 1801-1808, doi:10.1139/f99-128, 1999.

Kana, T. M., Darkangelo, C., Hunt, M. D., Oldham, J. B., Bennett, G. E., and Cornwell, J. C.: Membrane inlet mass spectrometer for rapid high-precision determination of $\mathrm{N}_{2}, \mathrm{O}_{2}$, and $\mathrm{Ar}$ in environmental water samples, Anal. Chem., 66, 4166-4170, doi:10.1021/ac00095a009, 1994.

Karl, D., Letelier, R., Tupas, L., Dore, J., Christian, J., and Hebel, D.: The role of nitrogen fixation in biogeochemical cycling in the subtropical North Pacific Ocean, Nature, 388, 533538, 1997.

Karl, D. M., Church, M. J., Dore, J. E., Letelier, R. M., and Mahaffey, C.: Predictable and efficient carbon sequestration in the North Pacific Ocean supported by symbiotic ni- 
trogen fixation., P. Natl. Acad. Sci. USA, 109, 1842-1849, doi:10.1073/pnas.1120312109, 2012.

Kitidis, V., Uher, G., Upstill-Goddard, R. C., Mantoura, R. F. C., Spyres, G., and Woodward, E. M. S.: Photochemical production of ammonium in the oligotrophic Cyprus Gyre (Eastern Mediterranean), Biogeosciences, 3, 439-449, doi:10.5194/bg-3439-2006, 2006.

Kranz, S. A., Levitan, O., Richter, K.-U., Prásil, O., BermanFrank, I., and Rost, B.: Combined effects of $\mathrm{CO}_{2}$ and light on the $\mathrm{N}_{2}$-fixing cyanobacterium Trichodesmium IMS101: physiological responses, Plant Physiol., 154, 334-345, 2010.

Leblanc, K., Cornet-Barthaux, V., Rodier, M., Desnues, A., Berthelot, H., Caffin, M., Héliou, J., and Moutin, T.: Response of phytoplanktonic community composition during a diazotroph bloom: a mesocoms approach, Biogeosciences Discuss., in prep., 2015.

Letscher, R. T., Hansell, D. A., Carlson, C. A., Lumpkin, R., and Knapp, A. N.: Dissolved organic nitrogen in the global surface ocean: distribution and fate, Global Biogeochem. Cy., 27, 141153, doi:10.1029/2012GB004449, 2013.

Lomas, M. W., Burke, A. L., Lomas, D. A., Bell, D. W., Shen, C., Dyhrman, S. T., and Ammerman, J. W.: Sargasso Sea phosphorus biogeochemistry: an important role for dissolved organic phosphorus (DOP), Biogeosciences, 7, 695-710, doi:10.5194/bg-7695-2010, 2010.

Longhurst, A. R.: Toward an ecological geography of the sea, in: Ecological Geography of the Sea, Academic Press, San Diego, 1-17, 2007.

Luo, Y.-W., Doney, S. C., Anderson, L. A., Benavides, M., BermanFrank, I., Bode, A., Bonnet, S., Boström, K. H., Böttjer, D., Capone, D. G., Carpenter, E. J., Chen, Y. L., Church, M. J., Dore, J. E., Falcón, L. I., Fernández, A., Foster, R. A., Furuya, K., Gómez, F., Gundersen, K., Hynes, A. M., Karl, D. M., Kitajima, S., Langlois, R. J., LaRoche, J., Letelier, R. M., Marañón, E., McGillicuddy Jr., D. J., Moisander, P. H., Moore, C. M., Mouriño-Carballido, B., Mulholland, M. R., Needoba, J. A., Orcutt, K. M., Poulton, A. J., Rahav, E., Raimbault, P., Rees, A. P., Riemann, L., Shiozaki, T., Subramaniam, A., Tyrrell, T., Turk-Kubo, K. A., Varela, M., Villareal, T. A., Webb, E. A., White, A. E., Wu, J., and Zehr, J. P.: Database of diazotrophs in global ocean: abundance, biomass and nitrogen fixation rates, Earth Syst. Sci. Data, 4, 47-73, doi:10.5194/essd-4-47-2012, 2012.

Mahaffey, C.: The conundrum of marine $\mathrm{N}_{2}$ fixation, Am. J. Sci., 305, 546-595, doi:10.2475/ajs.305.6-8.546, 2005.

Mather, R. L., Reynolds, S. E., Wolff, G. A., Williams, R. G., Torres-Valdes, S., Woodward, E. M. S., Landolfi, A., Pan, X., Sanders, R., and Achterberg, E. P.: Phosphorus cycling in the North and South Atlantic Ocean subtropical gyres, Nat. Geosci., 1, 439-443, doi:10.1038/ngeo232, 2008.

Mohr, W., Großkopf, T., Wallace, D. W. R., Laroche, J., and Grosskopf, T.: Methodological underestimation of oceanic nitrogen fixation rates, PLoS One, 5, e12583, doi:10.1371/journal.pone.0012583, 2010.

Moisander, P. H., Beinart, R. A., Hewson, I., White, A. E., Johnson, K. S., Carlson, C. A., Montoya, J. P., and Zehr, J. P.: Unicellular cyanobacterial distributions broaden the oceanic $\mathrm{N}_{2}$ fixation domain., Science, 327, 1512-1514, doi:10.1126/science.1185468, 2010.
Monteiro, F. M., Dutkiewicz, S., and Follows, M. J.: Biogeographical controls on the marine nitrogen fixers, Global Biogeochem. Cy., 25, 1-8, doi:10.1029/2010GB003902, 2011.

Montoya, J. P., Voss, M., Kahler, P., and Capone, D. G.: A simple, high-precision, high-sensitivity tracer assay for $\mathrm{N}_{2}$ fixation, Appl. Environ. Microb., 62, 986-993, 1996.

Montoya, J. P., Holl, C. M., Zehr, J. P., Hansen, A., Villareal, T. A., and Capone, D. G.: High rates of $\mathrm{N}_{2}$ fixation by unicellular diazotrophs in the oligotrophic Pacific Ocean., Nature, 430, 10271032, doi:10.1038/nature02824, 2004.

Moore, C. M., Mills, M. M., Achterberg, E. P., Geider, R. J., LaRoche, J., Lucas, M. I., McDonagh, E. L., Pan, X., Poulton, A. J., Rijkenberg, M. J. A., Suggett, D. J., Ussher, S. J., and Woodward, E. M. S.: Large-scale distribution of Atlantic nitrogen fixation controlled by iron availability, Nat. Geosci., 2, 867871, doi:10.1038/ngeo667, 2009.

Moore, J. K., Geider, R. J., Guieu, C., Jaccard, S. L., Jickells, T. D., LaRoche, J., Lenton, T. M., Mahowald, N. M., Marañón, E., Marinov, I., Nakatsuka, T., Oschlies, A., Saito, M. A., Thingstad, T. F., Tsuda, A., Ulloa, O.: Processes and patterns of nutrient limitation, Nat. Geosci., 6, 701-710, doi:10.1038/ngeo1765, 2013.

Moutin, T., Thingstad, T. F., Van Wambeke, F., Marie, D., Slawyk, G., Raimbault, P., and Claustre, H.: Does competition for nanomolar phosphate supply explain the predominance of the cyanobacterium Synechococcus?, Limnol. Oceanogr., 47, 15621567, doi:10.4319/lo.2002.47.5.1562, 2002.

Moutin, T., Van Den B, B., Beker, B., Dupouy, C., Rimmelin, P., and Le Bouteiller, A.: Phosphate availability controls Trichodesmium spp. biomass in the SW Pacific Ocean, Mar. Ecol.-Prog. Ser., 297, 15-21, doi:10.3354/meps297015, 2005.

Moutin, T., Karl, D. M., Duhamel, S., Rimmelin, P., Raimbault, P., Van Mooy, B. A. S., and Claustre, H.: Phosphate availability and the ultimate control of new nitrogen input by nitrogen fixation in the tropical Pacific Ocean, Biogeosciences, 5, 95-109, doi:10.5194/bg-5-95-2008, 2008.

Mulholland, M.: The Fate of nitrogen fixed by diazotrophs in the ocean, Biogeosciences, 4, 37-51,doi:10.5194/bg-4-37-2007, 2007.

Mulholland, M. and Capone, D.: Nitrogen fixation, uptake and metabolism in natural and cultured populations of Trichodesmium spp., Mar. Ecol.-Prog. Ser., 188, 33-49, doi:10.3354/meps188033, 1999.

Mulholland, M. R. and Bernhardt, P. W.: The effect of growth rate, phosphorus concentration, and temperature on $\mathrm{N}_{2}$ fixation, carbon fixation, and nitrogen release in continuous cultures of Trichodesmium IMS101, Limnol. Oceanogr., 50, 839-849, doi:10.4319/lo.2005.50.3.0839, 2005.

Mulholland, M. R., Ohki, K., and Capone, D. G.: Nitrogen utilization and metabolism relative to patterns of $\mathrm{N}_{2}$ fixation in cultures of Trichodesmium NIBB1067, J. Phycol., 35, 977-988, doi:10.1046/j.1529-8817.1999.3550977.x, 1999.

Nodder, S. and Waite, A.: Is Southern Ocean organic carbon and biogenic silica export enhanced by iron-stimulated increases in biological production? Sediment trap results from SOIREE, Deep-Sea Res. Pt. II, 48, 2681-2701,doi:10.1016/S09670645(01)00014-5, 2001.

Ouillon, S., Douillet, P., Lefebvre, J. P., Le Gendre, R., Jouon, A., Bonneton, P., Fernandez, J. M., Chevillon, C., Magand, O., 
Lefèvre, J., Le Hir, P., Laganier, R., Dumas, F., Marchesiello, P., Bel Madani, A., Andréfouët, S., Panché, J. Y., and Fichez, R.: Circulation and suspended sediment transport in a coral reef lagoon: the south-west lagoon of New Caledonia, Mar. Pollut. Bull., 61, 269-296, doi:10.1016/j.marpolbul.2010.06.023, 2010.

Painter, S. C., Sanders, R., Waldron, H. N., Lucas, M. I., and TorresValdés, S.: Urea distribution and uptake in the Atlantic Ocean between $50^{\circ} \mathrm{N}$ and $50^{\circ} \mathrm{S}$, Mar. Ecol.-Prog. Ser., 368, 53-63, doi:10.3354/meps07586, 2008.

Pujo-Pay, M. and Raimbault, P.: Improvement of the wet-oxidation procedure for simultaneous determination of particulate organic nitrogen and phosphorus collected on filters, Mar. Ecol.-Prog. Ser., 105, 203-207, doi:10.3354/meps105203, 1994.

Raimbault, P. and Garcia, N.: Evidence for efficient regenerated production and dinitrogen fixation in nitrogen-deficient waters of the South Pacific Ocean: impact on new and export production estimates, Biogeosciences, 5, 323-338, doi:10.5194/bg-5323-2008, 2008.

Redfield, A.: On the proportions of organic derivations in sea water and their relation to the composition of plankton, in: James Johnstone Memorial Volume, edited by: Daniel, R., University Press of Liverpool, Liverpool, 177-192, 1934.

Ridame, C., Guieu, C., and L'Helguen, S.: Strong stimulation of $N_{2}$ fixation in oligotrophic Mediterranean Sea: results from dust addition in large in situ mesocosms, Biogeosciences, 10, 73337346, doi:10.5194/bg-10-7333-2013, 2013.

Rodier, M. and Le Borgne, R.: Population dynamics and environmental conditions affecting Trichodesmium spp. (filamentous cyanobacteria) blooms in the south-west lagoon of New Caledonia, J. Exp. Mar. Biol. Ecol., 358, 20-32, doi:10.1016/j.jembe.2008.01.016, 2008.

Rodier, M. and Le Borgne, R.: Population and trophic dynamics of Trichodesmium thiebautii in the SE lagoon of New Caledonia. Comparison with T. erythraeum in the SW lagoon., Mar. Pollut. Bull., 61, 349-359, doi:10.1016/j.marpolbul.2010.06.018, 2010.

Shiozaki, T., Kodama, T., Kitajima, S., Sato, M., and Furuya, K.: Advective transport of diazotrophs and importance of their nitrogen fixation on new and primary production in the western Pacific warm pool, Limnol. Oceanogr., 58, 49-60, doi:10.4319/lo.2013.58.1.0049, 2013.

Shiozaki, T., Kodama, T., and Furuya, K.: Large-scale impact of the island mass effect through nitrogen fixation in the western South Pacific Ocean, Geophys. Res. Lett., 41, 2907-2913, doi:10.1002/2014GL059835, 2014.
Strickland, J. D. H. and Parsons, T. R.: A Practical Handbook of Seawater Analysis, Fisheries Research Board of Canada, Ottawa, 1972.

Subramaniam, A., Yager, P. L., Carpenter, E. J., Mahaffey, C., Björkman, K. M., Cooley, S., Kustka, A. B., Montoya, J. P., Sañudo-Wilhelmy, S. A., Shipe, R., and Capone, D. G.: Amazon River enhances diazotrophy and carbon sequestration in the tropical North Atlantic Ocean, P. Natl. Acad. Sci. USA, 105, 10460 10465, doi:10.1073/pnas.0710279105, 2008.

Thompson, A. W. and Zehr, J. P.: Cellular interactions: lessons from the nitrogen-fixing cyanobacteria, J. Phycol., 49, 1024-1035, doi:10.1111/jpy.12117, 2013.

Torres-Valdés, S., Roussenov, V. M., Sanders, R., Reynolds, S., Pan, X., Mather, R., Landolfi, A., Wolff, G. A., Achterberg, E. P., and Williams, R. G.: Distribution of dissolved organic nutrients and their effect on export production over the Atlantic Ocean, Global Biogeochem. Cy., 23, GB4019, doi:10.1029/2008GB003389, 2009.

Turk, K. A., Berman-Frank, I., Hogan, M. E., Desnues, A., Bonnet, S., and Zehr, J. P.: Diazotroph community composition shifts from diatom-associated Richelia- to Cyanothece-dominated during the VAHINE mesocosms experiment, Biogeosciences Discuss., in prep., 2015.

Villareal, T. A., Woods, S., Moore, J. K., and CulverRymsza, K.: Vertical migration of Rhizosolenia mats and their significance to $\mathrm{NO}_{3}^{-}$fluxes in the central North Pacific gyre, J. Plankton Res., 18, 1103-1121, doi:10.1093/plankt/18.7.1103, 1996.

Van Wambeke, F., Pfreundt, U., Moutin, T., Rodier, M., Berthelot, H., and Bonnet, S.: Dynamics of heterotrophic bacterial community during an experimental diazotrophic bloom in new Caledonia and links with transcriptional changes during the VAHINE mesocosms experiment, Biogeosciences Discuss., in prep., 2015.

Walsby, A. E.: The gas vesicles and buoyancy of Trichodesmium, in: Marine Pelagic Cyanobacteria: Trichodesmium and other Diazotrophs, vol. 362, edited by: Carpenter, E. J., Capone, D. G., and Rueter, J. G., Springer, Dordrecht, the Netherlands, 141-161, 1992.

Wangersky, P. J.: Sampling and analysis of particulate and dissolved matter, in: The Biology of Particules in Aquatic Systems, 2nd edn., edited by: Wotton, R. S., Lewis, CRC Press, 7-43, 1994.

White, A. E., Foster, R. A., Benitez-Nelson, C. R., Masqué, P., Verdeny, E., Popp, B. N., Arthur, K. E., and Prahl, F. G.: Nitrogen fixation in the Gulf of California and the Eastern Tropical North Pacific, Prog. Oceanogr., 109, 1-17, doi:10.1016/j.pocean.2012.09.002, 2012. 